\title{
Pocjena regionalnih platnih bilanci u Hrvatskoj
}

Filipić, Petar

Source / Izvornik: Odabrani prijevodi, 2016, 7, 1 - 38

Journal article, Published version

Rad u časopisu, Objavljena verzija rada (izdavačev PDF)

https://doi.org/10.3326/op.35

Permanent link / Trajna poveznica: https://urn.nsk.hr/urn:nbn:hr:242:775109

Rights / Prava: Attribution-NonCommercial-NoDerivatives 4.0 International/ImenovanjeNekomercijalno-Bez prerada 4.0 međunarodna

Download date / Datum preuzimanja: 2023-04-26

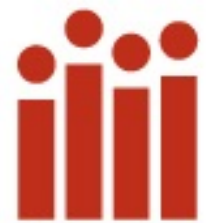

Repository / Repozitorij:

Institute of Public Finance Repository

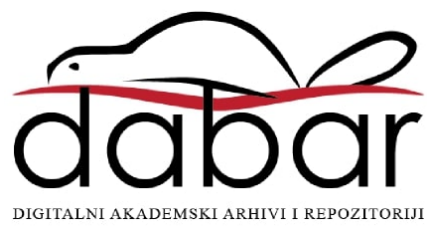


Institut za

javne financije

Smičiklasova 2I | Zagreb

www.ijf.hr | ured@ijf.hr

T: oI/4886-444 | F: OI/48I9-365

\section{ODABRANI}

\section{PRIJEVODI}

\section{BR. 35}

\section{6.}

ISSN I847-7445

citirati: Filipić, P., 20I6. The estimate of regional balances of payments in Croatia. Financial Theory and Practice, 40 (I), str. 85-I28. Dostupno na:

http://www.fintp.hr/upload/files/ft $\mathrm{p} / 20 \mathrm{I} 6 / \mathrm{I} /$ filipic.pdf $>$.

Svi Odabrani prijevodi dostupni su na: http://www.ijf.hr/hr/publikacije/ca sopisi/ı2/odabrani-prijevodi/III/

\section{PROCJENA REGIONALNIH PLATNIH BILANCI U HRVATSKOJ}

DR. SC. PETAR FILIPIĆ*

ČLANAK

JEL: RIO, E3I, E42

DOI: $10.3326 /$ op.35

\section{SAŽETAK}

Regija, kao dio države, i regionalni razvoj nisu u najužem fokusu teorije međunarodne razmjene. Razloga je više, kako teorijskih i metodoloških, tako i sasvim praktičnih, uključivo i nepostojanje adekvatne statistike, posebno one potrebne za izgradnju hrvatskih regionalnih bilanci. U tom smislu, nekoliko je ciljeva ovog rada. Nakon uvoda u kojem se ukazuje na ograničenja vođenja pojedinih regionalnih ekonomskih politika, slijedi poglavlje u kojem se definira sadržaj "idealne" regionalne platne bilance. Na putu od "idealnog" do "objektivnog" sadržaja regionalnih platnih bilanci, dakle onog uvjetovanog raspoloživim podatcima, moralo se razriješiti brojne metodološke probleme, $i$ ustrojiti odgovarajuću statistiku. U nastavku, analiza platnih bilanci otkriva cijelu skalu devizno pozitivnih i negativnih regija. Iako su kvantiteti pojedinih bilanci $i$ stavki sami za sebe zanimljivi, važna je spoznaja da različite regionalne izloženosti monetarnoj politici moguće zahtijevaju selektivni pristup ekonomske politike. Na kraju, koristeći regionalne platne bilance, analiziran je utjecaj deprecijacije kune na bruto domaći proizvod regija. Ustanovljeno je da bi se u pretpostavljenoj deprecijaciji, ako su devizne transakcije u odnosu na ostale ekonomske agregate tretirane ceteris paribus, dogodili značajni regionalni "dobici" i "gubici", koji bi vodili sve većoj razvojnoj nejednakosti na prostoru Hrvatske.

Ključne rijječi: regija, platna bilanca, tečaj valute, razvojni dispariteti, Hrvatska

*Autor zahvaljuje dvojici anonimnih recenzenata, te kolegama Nenadu Starcu i Draženu Koski na njihovim korisnim komentarima i sugestijama.

** Primljeno: 12. listopada 2015.

Prihvaćeno: I3. prosinca 20I5.

Petar FILIPIĆ

Sveučilište u Splitu, Ekonomski fakultet, Cvite Fiskovića 5, 2IOOo Split

e-mail: petar.filipic@efst.hr 


\section{UVOD, ILI, O NAGIONALNOJ I REGIONALNOJ EKONOMIJI I EKONOMSKOJ POLITICI}

Kada se $\mathrm{u}$ Hrvatskoj u razgovorima o pojedinim gospodarskim problemima kao prostorno-razvojne oznake koriste termini metropola i provincija tek malo je naboja potrebno da se na stol iznesu argumenti kako bi onima u provinciji najbolje bilo da sami upravljaju svojom ekonomijom ${ }^{\mathrm{I}}$. Jer, ton $\mathrm{u}$ tom trenutku postaje oštriji, provincija je manje razvijena i od prosjeka države, zatim, za oktavu više, izolirani su u svakom smislu sa svim posljedicama koje iz toga proizlaze, potom se u diskusiju uvlači argument koji ne trpi prigovor, da regiju karakterizira visoka osjetljivost okoliša što ponekad pomiče interes investitora izvan ovih područja, i, na kraju, ozvučeno udarcem šake o stol, sve dolazi „odozgo“ umjesto da se u upravljačkom pristupu dopusti ponešto i „odozdo“.

Tada se regija, bez obzira na unutrašnje nesuglasice i podjele, zamišlja kao ekonomski entitet u mnogim elementima sličan maloj državi s otvorenom ekonomijom na koju vanjski faktori imaju jak, ali ne presudan utjecaj. Zanimljivo je da su se regionalna teorija i teorija međunarodne razmjene često bavile sličnostima i razlikama nacionalne ekonomije i njenog manje ili više izoliranog dijela (regije).

Ako se taj teorijski okvir prilagodi posebnim zahtjevima (ne samo) hrvatske ekonomske scene (Filipić i Grčić, 2002.; Capello i Nijkamp, 2009.), može se uočiti:

- regije su na različitoj razvojnoj razini,

- u usporedbi s nacionalnom ekonomijom regionalne ekonomije su relativno više otvorene,

- ekonomija regije uže je povezana s ekonomijama drugih regija unutar nacionalne ekonomije nego različite nacionalne ekonomije međusobno,

- siromašnija ekonomska struktura čini regionalnu ekonomiju osjetljivom na različite mjere ekonomske politike.

Također, regionalne specifičnosti iziskuju različite regionalne razvojne politike jer:

- pojedine regije su više ili manje informacijski izolirane,

- pojedine regije karakterizira visoka osjetljivost okoliša,

- različite su im strukture urbanog sustava (Barca et al., 2012.), a i

- različiti su im inovativni kapaciteti patterns of innovation (Alderman i Davies, 1990.; Abreu et al., 2008.).

Najnovija svjetska gospodarska kriza aktualizirala je raspravu o specifičnostima (europskih) regionalnih ekonomija. Dva su aspekta u središtu pažnje (Camagni, 2015.). U zemljama članicama monetarne unije koje su činom pristupanja uniji "svedene" na regije, nemogućnost devalvacije valute za slučaj negativne trgovinske bilance, povećala je izloženost krizi, i produbila socijalne razlike, snažnije u slabije razvijenim regijama. I drugo, politika štednje (austerity policy) generira asimetrične efekte koji u situaciji smanjene javne potrošnje više pogađaju slabije razvijene regije ovisne o javnim transferima i unutrašnjoj potražnji, a porast kamatnih stopa odražava se na smanjenje investicija posebno vidljivo u industrijskim regijama.

Ono što je posebno važno, ograničene su mjere ekonomske politike koje regije imaju na raspolaganju za borbu protiv vlastitih ekonomskih problema (Filipić, 2000.). To se odnosi na sve ekonomske politike, posebno na najvažnije, fiskalnu i monetarnu. Pravila zajedničke nacionalne fiskalne politike vrijede i na regionalnoj razini. Iako smo svjedoci različitih vrsta i snage fiskalnih decentralizacija, najizdašniji proračunski prihodi uvijek su u rukama središnje (ekonomske) politike. Regija je dio

${ }^{\mathrm{I}}$ Više o ovoj temi (Filipić, 2006). 
područja zajedničke valute na kojem ponudu novca kontrolira središnja banka što znači da se ni u monetarnoj politici ne može tražiti instrumente i mjere za upravljanje vlastitim razvojem (Filipić, 200I.). Međutim, sve to ne znači da iz istraživačkog interesa trebaju biti uklonjene ove teme.

Jedan važan i vrlo aktualan segment ekonomske politike jest reguliranje odnosa s inozemstvom. U njemu se vanjskotrgovinska politika i politika cijena izravno isprepliću s monetarnom i deviznom politikom, a potom, putanjom multiplikatora, i s ostalim politikama, kako bi u konačnici za nacionalnu ekonomiju proizvele najpovoljniji rezultat. Sve je to u godišnjem iskazu zapisano u platnoj bilanci države koja predstavlja sistematičan prikaz vrijednosti ekonomskih transakcija (hrvatskih) rezidenata s inozemstvom u određenom razdoblju.

Kako je to slučaj u najvećem broju zemalja ni u Hrvatskoj se regionalne platne bilance ne izrađuju. Nakon što se to pedesetak godina uredno događalo, od 2012. se ni podatci o izvozu i uvozu županija više ne publiciraju. Tako će sigurno biti i ubuduće, jer je suvremena monetarna teorija umjesto okretanju regijama, potaknuta monetarnim pitanjima u eurozoni, reafirmirala i unaprijedila (Dellas i Taclas, 2009.; Cesarano, 2006.) gotovo zaboravljenu teoriju optimalnih valutnih područja (Mundell, 1963.). Svejedno, pored tih važnih teorija neka sasvim prizemna pitanja i dalje će tražiti odgovor. Poput sljedećeg, pretvorenog u case study na kraju ovog teksta: u kojoj mjeri promjena tečaja kune utječe na regionalne razvojne disparitete $\mathrm{u}$ Hrvatskoj?

Do odgovora na to pitanje pokušat će se doći uz pomoć, za potrebe ove analize konstruiranih, regionalnih platnih bilanci hrvatskih regija i županija.

\section{O PLATNOJ BILANGI I NJENIM REGIONALNIM (NE)MOGUĆNOSTIMA}

Svaki udžbenik međunarodne ekonomije ili makroekonomije na brojnim stranicama navodi sve o pojmu i strukturi platne bilance, o tehnikama knjiženja koje se u toj bilanci obavljaju, a veći dio teksta posvećen je politici njenog uravnoteženja (npr. Babić i Babić, 2008.). U brojnim metodološkim dokumentima koje u pravilu objavljuju središnje banke ( za Hrvatsku, HNB Godišnja izvješća) nalaze se definicije svake bilančne stavke i p(r)opisuju rezidenti koji su u rokovima i s obveznim sadržajem središnjoj banci i statistici dužni dostavljati građevne elemente platne bilance. U skladu s općeprihvaćenom teorijom, ali is uvjerenjem da je sve niže od nacionalne razine za makroekonomsku politiku nevažno, nigdje, baš nigdje u svim tim knjigama i izvedbenim dokumentima ne spominju se platne bilance užih teritorijalnih jedinica. Istina, $\mathrm{u}$ akademskim člancima regionalne platne bilance se spominju, i to u njihova tri aspekta: (I) kada se pod "regijom" podrazumijevaju države koje pripadaju ekonomskim, političkim ili zemljopisnim grupacijama, (2) u kontekstu rasprava o teoriji optimalnih valutnih područja, i (3) kada se dokazuje kako su diskusije o regionalnim platnim bilancama zapravo nepotrebne (npr. Ramos, 2006.) i diskusija usmjerava regionalnim bilancama tekućih transakcija (Ramos, 2007.).

Dakle, tema o regionalnim platnim bilancama uopće nije na dnevnom redu, ni teorije, niti prakse. Logično je stoga pitanje: odakle interes za izradu hrvatskih regionalnih platnih bilanci?

Jednom godišnje, svake godine, sastaju se hrvatski izvoznici (Brnić, 2015.). I uvijek iznova repetiraju zahtjev za korekciju tečaja kune. Na gore, naravno, jer, tu se s njima treba složiti, izvoz treba poticati na dobrobit cjelokupnog gospodarstva. Pri tom, utjecaji zahtijevane deprecijacije na ostale sudionike u gospodarskom životu se ne spominju, ni riječi o uvoznicima, na primjer. Više puta godišnje, svake godine, sastaju se dužnici s kreditima denominiranim u stranoj valuti ili u kunama uz valutnu 
klauzulu (Gatarić, 2015.) koji bi, sasvim logično, željeli da se tečaj ne mijenja, odnosno ako baš treba, neka to bude na nižu razinu, onu od prije nešto godina. Ni ova se interesna skupina u tečajnim kalkulacijama ne osvrće na ostale, devizni depoziti, na primjer, za njih su tabu tema. Za temu ovog teksta je važno da jedni i drugi, i svi ostali, žive i privređuju u sasvim konkretnom prostoru, $u$ županijama i regijama, te na mnogo načina dijele sudbinu vlastite gospodarske okoline. Hoće li promjena tečaja domaće valute poboljšati ili pogoršati ekonomsku situaciju u regiji/županiji? Hoće li pozitivna razlika regionalnih deviznih priljeva i odljeva voditi većem dohotku stanovnika regije i manjem broju nezaposlenih? Da bi se to saznalo treba krenuti od analize koja u konačnici, izvan dosega ovog rada, može rezultirati adekvatnim mjerama ekonomske politike, a primjeren analitički aparat su regionalne platne bilance.

Temeljnu razliku između nacionalne i regionalnih platni bilanci (sektorizacija prema Europskom sustavu nacionalnih i regionalnih računa - ESA 2010; European Commission, 2013.) čini sektor opće države sa svim svojim razinama. Njega u hrvatskim regionalnim platnim bilancama koje se u nastavku prezentiraju nema. Moguće je i državne transfere i državne zajmove po nekom ključu (na primjer strukturi BDP-a ili poreznih prihoda) razdijeliti na regije/županije, ali bi u tom slučaju regionalne platne bilance $u$ znatnoj mjeri (zbog velikih agregata državnih izvora i upotrebe fondova) izgubile specifičnosti. Svi ostali rezidenti iz nacionalne platne bilance su i u regionalnoj: (I) nefinancijska društva, (2) financijska društva (bez monetarnih institucija), (3) kućanstva, i (4) inozemstvo.

Promatrano po užim bilancama koje čine platnu bilancu (tablica I), bilanca tekućih transakcija (osim državnih transfera) po svom je sadržaju jednaka i za nacionalnu i regionalnu razinu. Razlika je tek u prostornom obuhvatu. Sve transakcije koje se u robnom, uslužnom i segmentu transfera obavljaju u stranoj valuti ili njihovoj kunskoj protuvrijednosti ovdje su popisane. Naravno, to čini razliku u odnosu na regionalne društvene račune koji i kunske međuregionalne transakcije tretiraju kao razmjenu regije s "inozemstvom".

Sve navedeno za bilancu tekućih transakcija odnosi se i na podbilancu dugoročni kapital u bilanci kapitalnih i financijskih transakcija, naravno osim na stavku državnih zajmova i zaduženja. Dakle, sva realna i portofolio ulaganja u ili iz inozemstva, koja svoje utočište ili ishodište imaju u regiji, mogu biti evidentirana i u regionalnoj platnoj bilanci.

Kriterij nacionalnih računa "domaće-inozemno", bespogovorno podrazumijeva da se sve u zemlji plaća u domaćoj, a preko granice u stranoj valuti. U regionalnim kratkoročnim bilancama kapitalnih i financijskih transakcija koje se ovdje prezentiraju taj je kriterij zamijenjen kriterijem "deviznokunsko" prema kojem je, osim županijske lokacije, jedino bitna valuta transakcije. Sve financijske transakcije regionalnih rezidenata $u$ devizama ili u kunama s deviznom klauzulom sadržaj su ovog segmenta regionalnih bilanci kapitalnih i financijskih transakcija. Na taj su način, ali ponegdje i zbog nedostataka podataka, na putu od nacionalnog do regionalnog stavke 7. i 8. modificirane i pretvorene $\mathrm{u}$ regionalne devizne kredite i depozite.

Konačno, račun rezervi. Iz prethodno navedenih razloga (razina opće države) njega nema na regionalnoj razini. Umjesto rezervi, u regionalnoj platnoj bilanci bilježi se saldo deviznog priljeva i odljeva. 
TABLICA I.

Sadržaj platne bilance

\begin{tabular}{|c|c|c|c|}
\hline \multicolumn{2}{|c|}{ Nacionalna razina - Hrvatska } & \multicolumn{2}{|c|}{ Regionalna/županijska razina } \\
\hline \multicolumn{2}{|c|}{ Bilanca tekućih transakcija } & \multicolumn{2}{|c|}{ Bilanca tekućih transakcija } \\
\hline Upotreba (duguje) & Izvori (potražuje) & Upotreba (duguje) & Izvori (potražuje) \\
\hline & \multicolumn{2}{|c|}{ A. Robe i usluge } \\
\hline \multicolumn{2}{|c|}{$\begin{array}{l}\text { A. Robe } 1 \text { usluge } \\
\text { I. Izvoz robe }\end{array}$} & \multicolumn{2}{|c|}{ I. Izvoz robe } \\
\hline \multicolumn{2}{|l|}{ Bilanca roba } & \multicolumn{2}{|l|}{ Bilanca roba } \\
\hline 2. Uvoz usluga & 2. Izvoz usluga & 2. Uvoz usluga & 2. Izvoz usluga \\
\hline 2.I. Turistička potrošnja u inozemstvu & 2.I. Potrošnja stranih turista u zemlji & 2.I. Turistička potrošnja u inozemstvu & 2.I. Potrošnja stranih turista u zemlji \\
\hline 2.2. Ostale usluge iz inozemstva & 2.2. Ostale usluge prodane inozemstvu & 2.2. Ostale usluge iz inozemstva & 2.2. Ostale usluge inozemstvu \\
\hline & & \multicolumn{2}{|l|}{ Bilanca usluga } \\
\hline \multicolumn{2}{|l|}{ Bilanca roba i usluga } & Bilanca roba i usluga & \\
\hline \multicolumn{2}{|c|}{ B. Transferi i dohoci } & \multicolumn{2}{|c|}{ B. Transferi i dohoci } \\
\hline 3. Transferi inozemcima & 3. Transferi iz inozemstva & 3. Transferi inozemcima & 3. Transferi iz inozemstva \\
\hline 3.I. Doznake stranih radnika zaposlenih u zemlji & 3.I. Doznake domaćih radnika iz inozemstva & 3.I. Doznake str. radnika zap. u zemlji & 3.I. Doznake domaćih radnika iz ino. \\
\hline 3.2. Mirovine plaćene strancima & 3.2. Mirovine domaćih rezidenata iz inozemstva & 3.2. Mirovine plaćene strancima & 3.2. Mirovine domaćih rezidenata iz ino. \\
\hline $\begin{array}{l}\text { 3.3. Ostali privatni transferi strancima } \\
\text { (kamate i dividende) }\end{array}$ & $\begin{array}{l}\text { 3.3. Ostali privatni transferi iz inozemstva (kamate i } \\
\text { dividende) }\end{array}$ & $\begin{array}{l}\text { 3.3. Ostali privatni transferi strancima } \\
\text { (kamate i dividende) }\end{array}$ & $\begin{array}{l}\text { 3.3. Ostali privatni transferi iz inozemstva } \\
\text { (kamate i dividende) }\end{array}$ \\
\hline 3.4. Državni transferi inozemstvu & 3.4. Državni transferni prihodi & & \\
\hline Saldo tekućih transfera & & Saldo tekućih transfera & \\
\hline 3.5. Naknade zaposlenima & 3.5. Naknade zaposlenima & 3.5. Naknade zaposlenima & 3.5. Naknade zaposlenima \\
\hline 3.6. Dohodak od FDI u domaćoj privredi & 3.6. Dohodak od FDI u inozemstvu & 3.6. Dohodak od FDI u domaćoj privredi & 3.6. Dohodak od FDI u inozemstvu \\
\hline 3.7. Dohodak od portfolio ulaganja & 3.7. Dohodak od portfolio ulaganja & 3.7. Dohodak od portfolio ulaganja & 3.7. Dohodak od portfolio ulaganja \\
\hline 3.8. Dohodak od ostalih ulaganja & 3.8. Dohodak od ostalih ulaganja & 3.8. Dohodak od ostalih ulaganja & 3.8. Dohodak od ostalih ulaganja \\
\hline \multicolumn{2}{|l|}{ Saldo dohodaka } & \multicolumn{2}{|l|}{ Saldo dohodaka } \\
\hline \multicolumn{2}{|c|}{ Bilanca kapitalnih i financijskih transakcija } & \multicolumn{2}{|c|}{ Bilanca kapitalnih i financijskih transakcija } \\
\hline Upotreba fondova (aktiva) & Izvori fondova (pasiva) & Upotreba fondova (aktiva) & Izvori fondova (pasiva) \\
\hline \multicolumn{2}{|c|}{ G. Dugoročni kapital } & \multicolumn{2}{|c|}{ C. Dugoročni kapital } \\
\hline 4. FDI inozemstvu & 4. FDI iz inozemstva & 4. FDI inozemstvu & 4. FDI iz inozemstva \\
\hline 5. Privatne investicije $u$ vrijed. papire $u$ inozemstvo & 5. Privatne inozemne portfolio investicije u zemlji & 5. Privatne investicije $u$ vr. papir. $u$ ino. & 5. Privatne ino. portfolio inv. u regiji \\
\hline 6. Državni zajmovi dani inozemstvu & 6. Državno zaduženje u inozemstvu & & \\
\hline \multicolumn{2}{|c|}{ D. Kratkoročni kapital } & \multicolumn{2}{|c|}{ D. Kratkoročni kapital } \\
\hline 7. Privatni trgovački krediti dani inozemcima & 7. Privatni trgovački krediti primljeni od inozemaca & & 7. Devizni krediti kreditnih institucija \\
\hline \multirow[t]{3}{*}{ 8. Privatni depoziti plasirani u ino. banke } & $\begin{array}{l}\text { 8. Privatni depoziti inozemaca plasirani u domaće } \\
\text { banke }\end{array}$ & 8. Devizni depoziti plasirani u banke & 7.I. Nefinancijskim društvima \\
\hline & & 8.I. Nefinancijskim društvima & 7.2. Kućanstvima \\
\hline & & 8.2. Kućanstvima & \\
\hline $\begin{array}{l}\text { 9. Privatne kupnje inozemnih novčanih } \\
\text { instrumenata }\end{array}$ & $\begin{array}{l}\text { 9. Privatna prodaja novčanih instrumenata } \\
\text { inozemcima }\end{array}$ & $\begin{array}{l}\text { 9. Privatne kupnje inozemnih novčanih } \\
\text { instrumenata }\end{array}$ & $\begin{array}{l}\text { 9. Privatna prodaja novčanih instrumenata } \\
\text { inozemcima }\end{array}$ \\
\hline Io. Državni zajmovi dani inozemstvu & Io. Državno zaduženje u inozemstvu & & \\
\hline \multicolumn{2}{|c|}{ Račun rezervi } & \multicolumn{2}{|c|}{ Saldo deviznog priljeva i odljeva } \\
\hline Uporaba sredstava (aktiva) & Izvori sredstava (pasiva) & Devizni odljev & Devizni priljev \\
\hline
\end{tabular}


Već je navedeno, platna je bilanca sistematičan prikaz vrijednosti ekonomskih transakcija rezidenata s inozemstvom u određenom razdoblju. Regionalne platne bilance, na način kako su posložene u ovom radu, zahtijevaju novu definiciju. One su sistematičan prikaz vrijednosti ekonomskih transakcija regionalnih rezidenata koje su, bez obzira da li s inozemstvom ili s domaćim rezidentima, obavljene u stranoj valuti (ili u kunama s deviznom klauzulom) u određenom razdoblju. Na taj način koncipirane, u svom značajnom dijelu, mogu se smatrati deviznim bilancama.

\section{IZVORI PODATAKA, ILI, PO TRNJU DO (REGIONALNIH) ZVIJEZDA}

Tri su vrste izvora podataka za sastavljanje nacionalne platne bilance: (I) izvješća državnih institucija: Državnog zavoda za statistiku (DZS) i Hrvatskog zavoda za mirovinsko osiguranje (HZMO), (2) specijalizirana izvješća Hrvatske narodne banke (HNB) o agregiranim platnim transakcijama s inozemstvom, dužničkim odnosima $\mathrm{s}$ inozemstvom, monetarnoj statistici i međunarodnim pričuvama, te (3) procjene i statistička istraživanja koje provodi HNB. U principu, robnu bilancu izrađuje DZS, Bilanca transfera u dijelu mirovina zadatak je HZMO-a, a ostalo, bilancu usluga, bez turizma, i stavke $\mathrm{u}$ bilanci kapitalnih i financijskih transakcija, temeljem izvještaja rezidenata, agregira HNB. Ovo "u principu” znači da unutar svih bilanci egzistiraju stavke koje se ili procjenjuju ili preuzimaju iz inozemnih izvora.

Svi ovi podatci pristižu od rezidenata koji obavljaju poslove s inozemstvom. U njihovim izvješćima postoji adresa rezidenta, njegova sjedišta ili boravišta, ovisno je li riječ o pravnim ili fizičkim osobama. Ta činjenica, da je poznata lokacija transakcije, upućuje na zaključak da je u "idealnoj” statistici moguće bez velikih problema sastaviti i regionalne platne bilance (odnosno regionalne društvene račune, uključivo regionalne input-output tablice). Ipak, to se ne radi, a neki razlozi tome, kojima treba pridodati visoki stupanj centralizacije svega i svačega u glavama i u praksi, navedeni su u prethodnom poglavlju. Stoga, da se izrade regionalne platne bilance bilo je potrebno identificirati gdje se podatci nalaze, zamoliti one koji te podatke posjeduju da ih preslože po županijama, tamo gdje ih uopće nema podatke procijeniti, i, u pojedinim slučajevima, koristiti podatke međunarodnih institucija.

Ali, evo konkretno koje je regionalne podatke porodilo preslagivanje hrvatskih baza podataka o platnoj bilanci.

Bilanca roba. U Hrvatskoj su se za uže teritorijalne jedinice godinama izrađivale bilance robnih odnosa s inozemstvom. Nekada su to bile zajednice općina, a na zahtjev se moglo dobiti i bilance općina. Potom su nastale županije za koje su se također uredno ove bilance izrađivale. Sve do 2012., zadnje u tom dugogodišnjem nizu, od kada ih DZS prestaje objavljivati. S članstvom u Europskoj uniji i udovoljavanjem zahtjevima Eurostata, robnih odnosa županija s inozemstvom (u javnosti) više nema. Premda kao članica EU-a mora ispunjavati njene zahtjeve, Hrvatska je konkretna zemlja sa svojim regionalnim identitetom. ${ }^{2}$ Stoga bi, iz analitičkih, gospodarskih i razloga ekonomske politike, vrlo važno bilo znati ekonomski, a ne samo politički razlog postojanja županija. Posebno ako "sirovi" podatci negdje postoje. Upravo je robna bilanca vremenski odredila regionalne platne bilance u ovom radu, izrađene su za 20I2. godinu. Dakle podatci nisu up-to-date, što dijelom umanjuje njihovu aktualnost, ali kako su promjene u platnoj bilanci u velikoj mjeri posljedica strukturnih promjena, temeljne tendencije vrijede i danas.

2 Članice EU-a uglavnom izrađuju regionalne bilance izvoza i uvoza roba i usluga. Tek kao primjer, UK 〈https://www.uktradeinfo.com/Statistics/RTS/Pages/default.aspx〉, i Njemačka 〈https://www.bundesbank.de/.../statso_II_balance_of_payments_by_region>. 
I jedna specifičnost koja rezultira iz visoke koncentracije gospodarskih aktivnosti u Zagrebu. Podatci DZS-a po županijama dobiveni su na osnovi razvrstavanja poduzeća koja su realizirala izvoz i uvoz u županiju (općinu, grad) u kojoj su registrirana prema Registru poslovnih subjekata. Na taj način gotovo $60 \%$ cjelokupnog uvoza roba (i 62\% usluga) obavljeno je u Zagrebu. Taj podatak (označen *), osim o koncentraciji, ukazuje na zaradu uvoznika smještenih u Zagrebu (a onda i o zaposlenima i uplaćenom porezu na dobit i dohodak), ali ne nudi informaciju o konačnoj alokaciji uvoza. Iz tog razloga, a u cilju veće realnosti regionalnih platnih bilanci, sačinjene su alternativne procjene (označene ${ }^{* *}$ ) koje uvoz roba i usluga raspodjeljuju po hrvatskom teritoriju u skladu sa strukturom BDP-a. Za razliku od uvoza, regionalni izvoz u značajnoj je korelaciji s BDP-om regija i nije ga trebalo korigirati. Na primjer, u istoj 2012., Grad Zagreb u hrvatskom izvozu sudjeluje s 37\%, a u BDP-u s 33\%.

Bilanca usluga. Dvije su stavke u ovoj bilanci. Prva, turistička (2.I.), za regionalnu je razinu procijenjena, jer takve bilance ne postoje. Za prihodnu stranu to je urađeno u tri koraka: (I) izračunat je devizni prihod od stranih turista prema potrošnji u komercijalnom smještaju po županijama kao umnožak broja noćenja stranih turista po županijama i dnevne potrošnje turista u komercijalnom smještaju $u$ eurima, (2) potom je devizni prihod prema potrošnji u komercijalnom smještaju izražen u postotcima za županije, i (3) tako izračunata struktura po županijama pomnožena je s ukupnim deviznim prihodima od turizma u Platnoj bilanci RH za 2012. Na strani dugovanja, turistička potrošnja domaćeg stanovništva $\mathrm{u}$ inozemstvu, dobivena je adaptacijom podataka o potrošnji $\mathrm{u}$ inozemstvu koje publiciraju DZS i Institut za turizam Zagreb. Ovako koncipirana, oslanja se na metodološko promišljanje pozicije turizma u platnoj bilanci Hrvatske (Galinec, 200o.). Izvori podataka korištenih u ovim procjenama navedeni su uz tablice A7, A8 i A9 u prilogu rada.

Druga stavka (2.2.), usluge iz inozemstva i usluge prodane inozemstvu, $u$ potpunosti je preuzeta iz nacionalne platne bilance s tim da su je zaposlenici Sektora statistike ${ }^{3}$ HNB-a, koristeći adrese rezidenata, "pretvorili" u regionalnu bilancu usluga.

Bilanca transfera $i$ dohodaka. Sastavljanje ove bilance za regionalnu razinu pokazalo se kao nepremostiv problem. Do mjere da podataka za niti jednu njenu stavku transfera i dohodaka $u$ regionalnim platnim bilancama nema. Na primjer, podatci o deviznim doznakama radnika iz inozemstva (3.I.) su (i pored "naredbe” HNB-a da ih, na propisanim obrascima, prijave) parcijalni, jer se većina deviznih prihoda osobno preuzima u inozemstvu. Za nacionalnu razinu tu uskače Svjetska banka, koja uz pomoć Međunarodnog monetarnog fonda svake godine za većinu zemalja svijeta izrađuje procjenu deviznih doznaka. U 2012. to je za Hrvatsku iznosilo gotovo I,I bil. eura4.

Kod mirovina (stavka 3.2.) je ponešto druga priča, ali za regionalne platne bilance s jednako nepovoljnim ishodom. U službenim statističkim evidencijama HZMO-a, primjera radi, na dan 3I. prosinca 2014. bilo je 153.72I korisnika kojima je mirovina određena primjenom međunarodnih ugovora o socijalnom osiguranju, a njihova prosječna mirovina iznosila je $742,38 \mathrm{kn}$. To rezultira godišnjim iznosom od gotovo I,4 bil. kuna, ili 180 mil eura. U broju 153.72I korisnika navedenih mirovina uključeni su korisnici kojima se mirovina upućuje u inozemstvo i $\mathrm{u}$ RH. Za mirovine koje HZMO isplaćuje u inozemstvo, $\mathrm{u}$ bazi podataka korisnika mirovina ne registrira se podatak o općini podrijetla, na osnovi koje bi se podatci mogli ispisati prema županijama, već inozemna adresa prebivališta korisnika koju je dojavio HZMO-u. Na drugoj strani, ne raspolaže se ni podatcima o

3 Zahvala autora zaposlenima u Sektoru statistike HNB-a za stručnost, dobronamjernost i strpljivost.

${ }_{4}^{4}$ Dostupno na: http://data.worldbank.org/indicator/BX.TRF.PWKR.CD.DT. 
korisnicima mirovina i mirovinskih primanja koji imaju prebivalište $\mathrm{u} R \mathrm{RH}$, a primaju mirovinu iz inozemstva, jer se isplata iz inozemstva obavlja direktno na račun korisnika mirovine, a ne preko HZMO-a.

Nedvojbeno je, regionalne platne bilance bile bi realnije da su u njih uključene devizne doznake i mirovine. Međutim, ove dvije stavke u sumarnom iznosu (oko I,3 mil. eura) čine manje od 3\% od ukupnih deviznih priljeva regionalnih platnih bilanci (oko 42 mil. eura), što znači da je (ipak) postignuta visoka razina pouzdanosti dobivenih rezultata.

Bilanca kapitalnih i financijskih transakcija. Kako je to urađeno u nacionalnoj platnoj bilanci i u regionalnim bilancama kapitalnih i financijskih transakcija sve su transakcije podijeljene na dugoročne i kratkoročne. Od dugoročnih transakcija, za privatne investicije u vrijednosne papire $u$ inozemstvo i privatne inozemne portfolio investicije $\mathrm{u}$ zemlji (stavka 5. u tablici $\mathrm{I}$ ) podatci za razine niže od nacionalne ne postoje. Kada su u pitanju izravna ulaganja (stavka 4.), HNB posjeduje podatke i za strana ulaganja u zemlji kao i za ulaganja iz zemlje u inozemstvo. Metodologija za inozemna izravna ulaganja u regionalnim platnim bilancama prati nacionalnu metodologijus, s tim da se i ovdje Sektor statistike HNB-a iskazao, pretvarajući za potrebe ovog rada nacionalne u županijske podatke. Podatci o stranim ulaganjima usklađeni su s najnovijim zahtjevima statistike (BPM6) EU-a koja je preuzela metodologiju Međunarodnog monetarnog fonda (IMF, 2009.) ${ }^{6}$.

Segment kratkoročni kapital u regionalnoj bilanci kapitalnih i financijskih transakcija u osnovnoj ideji evidentira kredite i depozite na isti način kao i u nacionalnoj platnoj bilanci. Osim što je riječ o različitim razinama prostornog obuhvata, važna je i sadržajna razlika. Na regionalnoj razini obuhvaćeni su svi inozemni i domaći krediti (stavka 8) i depoziti (stavka 7) ako je transakcija izvršena u devizama ili u kunama s deviznom klauzulom?7. Za privatne prodaje novčanih instrumenata (stavka 9) ne postoje podatci za razinu nižu od nacionalne.

Račun rezervi. Suma salda bilance tekućih transakcija i bilance kapitalnih transakcija u nacionalnoj platnoj bilanci jednaka je promjenama rezervi. Iako se $\mathrm{u}$ regionalnim platnim bilancama, koncipiranim za potrebe ovog rada, iskazuje saldo svih transakcija iskazanih u bilancama tekućih i kapitalnih transakcija, račun rezervi kao konačno zatvaranje platne bilance ne postoji, jer ne postoji potreba pokrivanja vremenskog jaza između deviznih prihoda i rashoda.

Podatci koji su bili na raspolaganju odredili su konačan izgled regionalnih platnih bilanci. Zajedno s iznosima pojedinih stavki, ukupna bilanca za sve županije prikazana je u tablici 2. u nastavku rada.

\section{REZULTATI}

Dezagregiranje stavki nacionalne platne bilance po regionalnom uzorku otkriva nam obujam transakcija koje regionalna razina obavlja u devizama (ili u kunskoj protuvrijednosti). Kako je već istaknuto, riječ je o svojevrsnoj deviznoj bilanci županija. Nažalost, podatci su samo za 2012., jer za važne stavke (uvoz i izvoz) novijih nema, a vraćanje u prošlost, koje bi urodilo kvalitetnijim zaključcima, nadilazi fizičke kapacitete pojedinca. Svejedno, prikupljeni i obrađeni podatci za

\footnotetext{
5 Dostupno na: http://www.hnb.hr/statistika/strana-ulaganja/h-info-nova-metodologija.pdf.

${ }^{6}$ Detaljnija objašnjenja o uvođenju standarda BPM6 (Načelo imovine i obveza) umjesto BPM5 (Načelo smjera ulaganja) na: http://www.hnb.hr/statistika/esa-20Io/h-esa-prezentacija-skudar.pdf.

7 Metodologija prati: http://www.hnb.hr/statistika/statisticki_pregled/hmetod.pdf, odnosno tablice D5 Statističkog pregleda HNB-a za institucionalne sektore.
} 
analiziranu jednu godinu rasvjetljavaju unutarhrvatsku deviznu sliku koja, u temeljnim agregatima i strukturi, vrijedi i danas.

Nekoliko je važnih informacija sadržano u tablici 2. Prije svega ona o ukupnom obujmu transakcija. Županije, sve zajedno, u 2012. obavile su deviznih transakcija koje gotovo dosežu ukupni hrvatski BDP. U brojkama, te je godine hrvatski BDP iznosio gotovo 44 mil. eura, a devizne transakcije na strani odljeva 39,5 mil. eura (oko 90\% BDP-a), odnosno na strani priljeva 42 mil. eura (oko 96\% BDP-a). Dakle, riječ je o vrlo značajnim sredstvima koja, u ponešto različitim rješenjima (de)centralizacije politike i ekonomske politike mogu, utjecati na razvoj regionalne razine.

\section{TABLICA 2.}

Svodna platna bilanca svih županija 20I2., u mil. eura

\begin{tabular}{|c|c|c|c|}
\hline \multicolumn{4}{|c|}{ Svodna platna bilanca županija } \\
\hline \multicolumn{4}{|c|}{ Bilanca tekućih transakcija } \\
\hline Upotreba (duguje) & & Izvori (potražuje) & \\
\hline \multicolumn{4}{|c|}{ A. Robe i usluge } \\
\hline I. Uvoz robe & I6.I47,I & I. Izvoz robe & $9.605,7$ \\
\hline Bilanca roba & $6.541,4$ & & \\
\hline 2. Uvoz usluga & $2.526,7$ & 2. Izvoz usluga & $8.890,3$ \\
\hline 2.I. Turistička potrošnja u inozemstvu & I.OI6,5 & 2.I. Potrošnja stranih turista u zemlji & $6.858,7$ \\
\hline 2.2. Ostale usluge iz inozemstva & $\mathrm{I} .5 \mathrm{IO}, 2$ & 2.2. Ostale usluge inozemstvu & $2.031,6$ \\
\hline Bilanca usluga & & & $6.363,6$ \\
\hline Bilanca roba i usluga & 177,8 & & \\
\hline \multicolumn{4}{|c|}{ Bilanca kapitalnih i financijskih transakcija } \\
\hline Upotreba fondova (aktiva) & & Izvori fondova (pasiva) & \\
\hline \multicolumn{4}{|c|}{ C. Dugoročni kapital } \\
\hline 4. FDI inozemstvu & $-63,5$ & 4. FDI iz inozemstva & I.IO9,2 \\
\hline Bilanca dugoročnog kapitala & & & $\mathrm{I} . \mathrm{I} 72,8$ \\
\hline \multicolumn{4}{|c|}{ D. Kratkoročni kapital } \\
\hline 8. Devizni depoziti plasirani u banke & $20.883,2$ & 7. Devizni krediti kreditnih institucija & $22.5 \mathrm{I} 8,8$ \\
\hline 8.I. Nefinancijskim društvima & $2.291,0$ & 7.I. Nefinancijskim društvima & $9.265,5$ \\
\hline 8.2. Kućanstvima & $18.592,2$ & 7.2. Kućanstvima & $13.253,4$ \\
\hline Bilanca kratkoročnog kapitala & & & I.635,6 \\
\hline Bilanca kapitalnih i financijskih transakcij & & & $2.808,4$ \\
\hline \multicolumn{4}{|c|}{ Bilanca deviznog priljeva i odljeva svih županija } \\
\hline Devizni odljev & & Devizni priljev & \\
\hline & $39.493,5$ & & 42.124, $\mathrm{O}$ \\
\hline Saldo deviznog priljeva i odljeva & & & $2.630,6$ \\
\hline
\end{tabular}

Svodna županijska bilanca je pozitivna: devizni priljevi veći su od deviznih odljeva. Saldo od 2,6 bil. eura govori da su devizni odljevi za gotovo $7 \%$ manji od priljeva. Naravno, ovdje treba napomenuti da $u$ regionalnoj platnoj bilanci nema transfera i dohodaka, kao ni opće države, njenih izvora i upotrebe, a što bi, kako je objašnjeno u odjeljku 2., utjecalo na ovaj saldo.

Promatrano po strukturi, realni sektor predočen Bilancom tekućih transakcija na strani upotrebe realizira $47,3 \%$, a na strani izvora 43,9\% svih transakcija obuhvaćenih svodnom bilancom. Dakle, prevaga je na strani kapitalnih i financijskih transakcija. Posljedično, a u to se uvjeravamo i danas, visoka je izloženost gospodarstva i stanovništva deviznom riziku po osnovi transakcija s bankarskim sektorom.

Konačno, podbilance. Uvoz roba je veći od izvoza, uvoz usluga je manji od njihova izvoza kako u turizmu tako i u ostalim uslugama, strane su investicije veće od naših investicija u inozemstvo, devizni krediti nefinancijskom sektoru četiri su puta veći od deviznih depozita tog sektora, a devizni 
depoziti stanovništva 40\% su veći od njihovih deviznih kredita. Svi su ovi odnosi uglavnom poznati iz statistike DZS-a o platnoj bilanci zemlje.

Ono što nije poznato je teritorijalni raspored ovih platnobilančnih stavki i njihovih salda. Podatci u tablici 3 svodne brojke iz posljednjeg retka tablice 2. rasprostiru u hrvatski prostor.

\section{TABLICA 3.}

Saldo regionalnih bilanci deviznog priljeva i odljeva u 20I2. po NUTS 2, makroregijama i županijama, u mil. eura

\begin{tabular}{|c|c|c|}
\hline \multirow{2}{*}{ NUTS 2, makroregija, županija } & \multicolumn{2}{|c|}{ Regionalna bilanca } \\
\hline & SRDB $^{*}$ & PRDB** \\
\hline \multicolumn{3}{|c|}{ Zagrebačka ili središnja hrvatska makroregija } \\
\hline Zagrebačka županija & $-283,5$ & $-17,8$ \\
\hline Krapinsko-zagorska županija & II 3,7 & 70,5 \\
\hline Sisačko-moslavačka županija & 390,3 & $124, \mathrm{O}$ \\
\hline Karlovačka županija & 40,7 & $-\mathrm{I} 7 \mathrm{O}, 2$ \\
\hline Varaždinska županija & 549,6 & 503,9 \\
\hline Koprivničko-križevačka županija & 256,4 & $\mathrm{I} 8, \mathrm{I}$ \\
\hline Bjelovarsko-bilogorska županija & 60,6 & $-\mathrm{I} 33,3$ \\
\hline Međimurska županija & $2 \mathrm{I}, 6$ & $-47, I$ \\
\hline Ukupno bez Zagreba & I.I48,8 & 348,0 \\
\hline Grad Zagreb & $-4.685, I$ & 247,0 \\
\hline Zagrebačka makroregija ukupno & $-3 \cdot 536,3$ & $595, \mathrm{I}$ \\
\hline \multicolumn{3}{|l|}{ Osječka ili slavonska makroregija } \\
\hline Virovitičko-podravska županija & I2I,3 & $-5,9$ \\
\hline Požeško-slavonska županija & 63,0 & $-54,7$ \\
\hline Brodsko-posavska županija & 94,8 & $-66,0$ \\
\hline Osječko-baranjska županija & 752,8 & I8I,I \\
\hline Vukovarsko-srijemska županija & $\mathrm{I} 39,5$ & $-72,7$ \\
\hline Osječka makroregija ukupno & I.I7I,3 & $-\mathrm{I} 8,2$ \\
\hline NUTS 2 Kontinentalna Hrvatska & $-2.365,0$ & 576,9 \\
\hline \multicolumn{3}{|c|}{ Riječka ili primorsko-goranska makroregija } \\
\hline Primorsko-goranska županija & $1.064,3$ & $\mathrm{I} 32,7$ \\
\hline Ličko-senjska županija & $\mathrm{I} 74, \mathrm{O}$ & 30,5 \\
\hline Istarska županija & $\mathrm{I} .840,2$ & $\mathrm{I} .5 \mathrm{I} 2,2$ \\
\hline Riječka makroregija ukupno & $3.078,5$ & I. 675,4 \\
\hline \multicolumn{3}{|l|}{ Splitska ili dalmatinska makroregija } \\
\hline Zadarska županija & 732,0 & $35 \mathrm{I}, 2$ \\
\hline Šibensko-kninska županija & I.OOI,I & 920,9 \\
\hline Splitsko-dalmatinska županija & $-453,0$ & $-1.159,8$ \\
\hline Dubrovačko-neretvanska županija & 637,0 & 265,9 \\
\hline Splitska makroregija ukupno & I.917,0 & 378,2 \\
\hline NUTS 2 Jadranska Hrvatska & $4.995,5$ & $2.053,7$ \\
\hline RH ukupno & $2.630,6$ & $2.630,6$ \\
\hline
\end{tabular}

Tablica 3, kao i sve tablice u nastavku, sadrži dvije varijante salda bilanci deviznog priljeva i odljeva užih teritorijalnih jedinica U prvoj, označenoj (*), podatci po županijama dobiveni su na osnovi razvrstavanja poduzeća koja su realizirala uvoz i izvoz robe i usluga u županiju (općinu, grad) u kojoj su registrirana prema Registru poslovnih subjekata. To je uobičajeni pristup u službenoj statistici stoga ova varijanta bilance u nazivu ima S. Druga varijanta, označena $(* *)$, procjenjuje (stoga $\mathrm{P})$ uvoz roba i usluga po županijama dijeljenjem ukupnog hrvatskog uvoza prema županijskoj strukturi BDP-a. Takva se raspodjela uvoza može opravdati direktnim uvoznim koeficijentom koji se izračunava stavljanjem uvoza u odnos s BDP-om. Ostale podbilance (turizam, dugoročni i kratkoročni kapital) jednake su u obje varijante regionalnih platnih bilanci. 
Osim podataka za dvadeset županija i Grad Zagreb, u tablici 3 izvršena su i regionalna agregiranja. U skladu s europskim kriterijima Hrvatska je podijeljena na dvije NUTS 2 regije, Kontinentalnu i Jadransku Hrvatsku (Zakon o regionalnom razvoju Republike Hrvatske, NN 147/I4.), a također, prema regionalizaciji iz Hrvatske enciklopedije (Leksikografski zavod Miroslav Krleža, 2013-2015.) i na četiri makroregije: Zagrebačku, Osječku, Riječku i Splitsku.

Svi izvori, kako za metodologiju alternativnih bilanci, tako i za definicije regionalnih jedinica, navedeni su uz tablice u prilogu ovog rada.

U “službenoj” varijanti (*), sve županije osim Zagrebačke, Grada Zagreba i Splitsko-dalmatinske su devizno pozitivne. Uvoz roba je stavka koja uvjetuje takav raspored uspješnosti. Vrlo niska pokrivenost uvoza roba njihovim izvozom doveo je cijelu Zagrebačku makroregiju, čak i NUTS 2 Kontinentalnu Hrvatsku, do negativnog salda. U Splitsko-dalmatinskoj županiji negativnom saldu deviznog priljeva i odljeva osim uvozno-izvoznog deficita pridonosi i naglašeno velika razlika kredita i depozita.

\section{GRAFIKON I.}

Saldo regionalnih bilanci deviznog priljeva i odljeva* po županijama 2012.

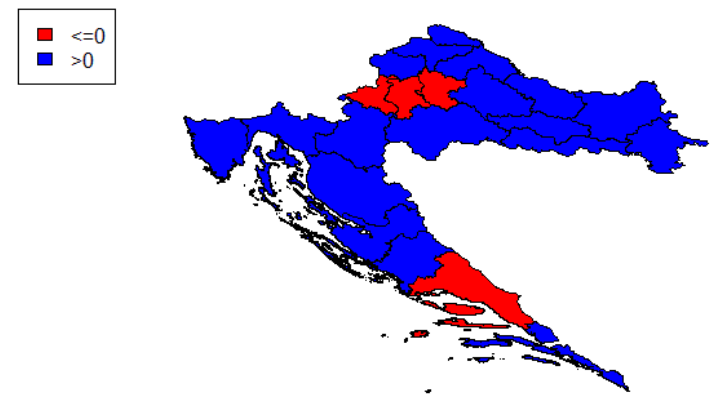

Slika je različita i, čini se, realnija ako se uvoz raspodijeli po kriteriju BDP-a. Naime, ovaj kriterij "približava” uvoz njegovoj konačnoj namjeni i točniji je od evidencije po adresi uvoznog poduzeća. Za odgovor na pitanje, koliko točniji, trebalo bi raspolagati podatcima (zagrebačkih, uglavnom) uvoznika o konačnoj destinaciji uvezene robe.

Umjesto tri županije, $u$ ovoj procijenjenoj varijanti regionalnih bilanci negativni saldo iskazuje njih deset, s tim da među njima više nije Grad Zagreb. On je svoj negativni saldo isporučio u svoju okolinu i na istok, u Slavoniju. Posljedica ove transformacije uvoza je da su obje NUTS 2 regije i tri makroregije (osim Osječke) devizno pozitivne. 
GRAFIKON 2.

Saldo regionalnih bilanci deviznog priljeva i odljeva ** po županijama 2012.

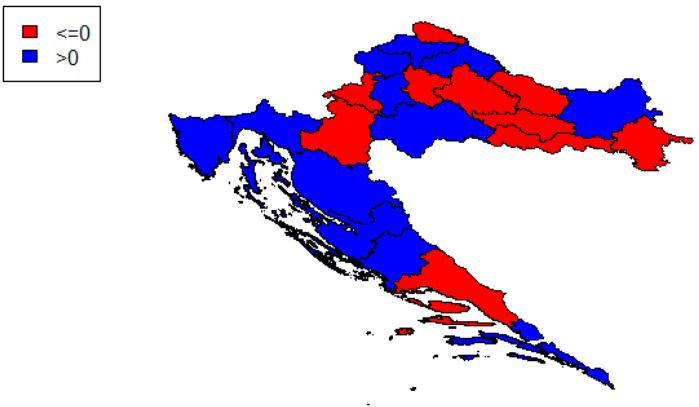

Statistika županija koja otkriva devizno pozitivne i negativne, u kojoj neke imaju trgovinske ili kapitalne viškove, a druge manjkove, nameće jedno sasvim obično pitanje: je li dobro biti u plusu, a loše u minusu? Odgovor na to pitanje vodi nas trima situacijama: (I) teorijski poželjnoj ravnoteži, koja se iz niza (uglavnom strukturnih) razloga nikada ne postiže, pogotovo na regionalnoj razini gdje je veća otvorenost pozitivno korelirana s razvojnim šansama, (2) pozitivnoj bilanci, koja do određene pozitive potiče gospodarski razvoj i ne izaziva prigovore okoline, i (3) negativnom saldu, koji svakim većim postotkom izaziva sve veće platnobilančne probleme. Iako je na prvi pogled izbor jednostavan ne treba zaboraviti da smo unutar ekonomske teorije i prakse $u$ kojima ono što je očigledno često vara. Stoga, iako je "pozitivno” dobro, a "negativno" loše, za konačnu ocjenu uspješnosti, platnu bilancu svake regionalne jedinice treba smjestiti u nacionalni i njen regionalni ekonomski okvir, u kontekst ekonomske analize, kako bismo točnije dali odgovor na prethodno postavljeno pitanje. U osnovi, to nije zadatak ovog rada. Ipak, da regionalne platne bilance ne bi bile tek statistički iskaz i živjele ceteris paribus izdvojene, u nastavku se dovode u vezu s BDP-om.

Uobičajeno je mjeriti uključenost neke ekonomije u međunarodnu razmjenu udjelom izvoza i/ili uvoza roba i usluga u BDP-u. Tako se ekonomije uspoređuju i rangiraju. S obzirom na heterogenu strukturu platne bilance, u njoj su i fondovi, ona se iznimno uspoređuje s BDP-om. Kako su regionalne platne bilance predstavljene $u$ ovom radu sasvim specifične, argumenti su izneseni na prethodnim stranicama, a kako je prirodna potreba istraživača uspoređivati i rangirati, definiran je indikator uključenosti pojedinih regionalnih jedinica $u$ hrvatske devizne transakcije ( $\mathrm{u}$ zemlji i inozemstvu). $\mathrm{U}$ indikatoru je ukupan obujam deviznih transakcija regionalnih jedinica (UODT), onih na strani priljeva i na strani odljeva, najprije stavljen u odnos s BDP-om tih jedinica, a potom uspoređen s hrvatskim prosjekom. U rezultatu je indeks uključenosti koji smješta (i rangira) regionalne jedinice oko hrvatskog prosjeka. Ista je procedura ponovljena i za drugi indikator, s tim da je umjesto BDP-a u njegovom nazivniku broj stanovnika regionalne jedinice. Dodatne bi analitičke koristi bile i od indikatora koji zasebno analiziraju devizne priljeve, a zasebno odljeve, ali taj istraživački užitak neka pripadne nekoj drugoj prilici ili nekom drugom analitičaru. 
TABLICA 4.

Ukupan obujam deviznih transakcija (UODT) po jedinici BDP-a i po stanovniku, po NUTS 2, makroregijama i županijama u 2012., Hrvatska=100

\begin{tabular}{|c|c|c|c|c|}
\hline NUTS 2, makroregija, županija & UODT*/BDP & UODT $^{* *} / \mathrm{BDP}$ & $\begin{array}{l}\text { UODT*/po } \\
\text { stanovniku }\end{array}$ & $\begin{array}{l}\text { UODT }^{* *} / \text { po } \\
\text { stanovniku }\end{array}$ \\
\hline \multicolumn{5}{|c|}{ Zagrebačka ili središnja hrvatska makroregija } \\
\hline Zagrebačka županija & 99,6 & 93,8 & 75,8 & $7 \mathrm{I}, 4$ \\
\hline Krapinsko-zagorska županija & 87,9 & 90,7 & $53, \mathrm{I}$ & 54,8 \\
\hline Sisačko-moslavačka županija & 63,7 & $74, \mathrm{I}$ & 49,7 & 57,8 \\
\hline Karlovačka županija & 65,5 & 77,3 & 48,0 & 56,5 \\
\hline Varaždinska županija & 98,5 & IOO,2 & 79,4 & 80,7 \\
\hline Koprivničko-križevačka županija & 58,6 & 70,8 & 52,0 & 62,8 \\
\hline Bjelovarsko-bilogorska županija & $63, \mathrm{I}$ & 76,0 & $4 \mathrm{I}, 8$ & 50,3 \\
\hline Međimurska županija & 88,3 & 92,2 & 72,5 & 75,7 \\
\hline Ukupno bez Zagreba & $8 \mathrm{I}, 7$ & $86, \mathrm{I}$ & 62,0 & 65,2 \\
\hline Grad Zagreb & II3,6 & 95,5 & 205,7 & 172,9 \\
\hline Zagrebačka makroregija ukupno & IOO,8 & 91,7 & II6,9 & IO6,4 \\
\hline \multicolumn{5}{|l|}{ Osječka ili slavonska makroregija } \\
\hline Virovitičko-podravska županija & 63,3 & 76,5 & 37,8 & 45,7 \\
\hline Požeško-slavonska županija & 68,9 & 82,5 & 40,3 & 48,2 \\
\hline Brodsko-posavska županija & 75,7 & $85, \mathrm{I}$ & 42,8 & $48, \mathrm{I}$ \\
\hline Osječko-baranjska županija & 68,9 & $8 \mathrm{I}, 5$ & 54,0 & 63,8 \\
\hline Vukovarsko-srijemska županija & 59,6 & 70,4 & 34,5 & 40,7 \\
\hline Osječka makroregija ukupno & 67,7 & 79,5 & 44,4 & 52,2 \\
\hline NUTS 2 Kontinentalna Hrvatska & 94,8 & 89,5 & 96,6 & $9 \mathrm{I}, 2$ \\
\hline \multicolumn{5}{|c|}{ Riječka ili primorsko-goranska makroregija } \\
\hline Primorsko-goranska županija & 86,9 & 99,8 & IIO,7 & 127,2 \\
\hline Ličko-senjska županija & 77,2 & 97,2 & 57,4 & 72,2 \\
\hline Istarska županija & I38,5 & $\mathrm{I} 45,3$ & 170,9 & 179,2 \\
\hline Riječka makroregija ukupno & IO6,I & II7, O & $\mathrm{I} 28,4$ & I4I, 6 \\
\hline \multicolumn{5}{|l|}{ Splitska ili dalmatinska makroregija } \\
\hline Zadarska županija & $\mathrm{II} 3,5$ & $\mathrm{I} 28,2$ & 9I,O & IO2,7 \\
\hline Šibensko-kninska županija & $\mathrm{I} 68, \mathrm{I}$ & $\mathrm{I} 73,2$ & $\mathrm{I} 26,9$ & I3O,8 \\
\hline Splitsko-dalmatinska županija & IO3,3 & II 3,9 & 79,3 & 87,5 \\
\hline Dubrovačko-neretvanska županija & $\mathrm{I} 22, \mathrm{O}$ & I38,6 & II 7,2 & I33,I \\
\hline Splitska makroregija ukupno & II6,3 & $\mathrm{I} 28, \mathrm{I}$ & 93,I & IO2,6 \\
\hline NUTS 2 Jadranska Hrvatska & III,2 & $\mathrm{I} 22,6$ & I07,0 & II7,9 \\
\hline RH ukupno & IOO & IOO & IOO & IOO \\
\hline
\end{tabular}

Jedna zemlja, dvije (devizne) ekonomije. Ili čak tri, jer Grad Zagreb je priča za sebe. Uz časni izuzetak Varaždinske, sve županije smještene u Kontinentalnoj Hrvatskoj prema prvom indikatoru ispod su hrvatskog prosjeka. Obujam njihovih deviznih transakcija u odnosu na BDP smješta se između 58 i $85 \%$ hrvatskog prosjeka. U Jadranskoj Hrvatskoj tek Ličko-senjska županija dijeli istu sudbinu. Sve ostale županije, osim Splitsko-dalmatinske po stanovniku, iznad su hrvatskog, ali i zagrebačkog prosjeka.

Pokazatelji po stanovniku povećavaju regionalne razlike: Osječka makroregija tek je iznad polovine hrvatskog prosjeka, a Zagrebačka (bez Grada Zagreba) je na dvije trećine tog prosjeka. Dok se Splitska makroregija po ovom pokazatelju spušta na hrvatski prosjek, Riječka makroregija ozbiljno konkurira Gradu Zagrebu.

Već je istaknuto, sve te razlike ne moraju značiti da je prostor Jadranske Hrvatske bogatiji i da je tamo bolje živjeti i poslovati, a da je u Kontinentalnoj Hrvatskoj sve to lošije. Ono na što brojke upućuju je da postoji različita razina izloženosti županija gotovo svim instrumentima i mjerama monetarne politike (tečaju, inflaciji, deviznim intervencijama, kamatama, itd.). To bi zahtijevalo selektivni pristup 
monetarne politike (i fiskalne, naravno), iako takav zahtjev u pravilu navlači ironičan i/ili kiseli osmjeh na lica nositelja te politike. Jer, u prilog takvog zahtjeva, iako nevoljko, ponekad treba posegnuti i za najtežom artiljerijom, ustavnom i zakonskom regulativom o ravnomjernosti razvoja $u$ kojoj se inzistira na povezanosti lokalnih i regionalnih razvojnih potreba s prioritetima razvoja središnje razine i donošenju mjera za ravnomjeran razvoj jedinica lokalne i područne (regionalne) samouprave.

\section{TABLICA 5.}

Salda podbilanci regionalnih platnih bilanci 20I2., po NUTS 2, makroregijama i županijama, u mil. eura

\begin{tabular}{|c|c|c|c|c|c|c|c|}
\hline \multirow[t]{2}{*}{ NUTS 2, makroregija, županija } & \multicolumn{2}{|c|}{$\begin{array}{l}\text { Robna razmjena } \\
\text { Izvoz (+) Uvoz (-) }\end{array}$} & \multicolumn{2}{|c|}{$\begin{array}{c}\text { Razmjena usluga } \\
\text { Prihodi (+) Rashodi (-) }\end{array}$} & \multirow{2}{*}{$\begin{array}{c}\text { Turistička } \\
\text { aktivnost } \\
\text { Stranci (+) } \\
\text { Domaći (-) } \\
\text { Saldo }\end{array}$} & \multirow{2}{*}{ 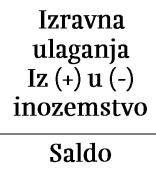 } & \multirow{2}{*}{$\begin{array}{c}\begin{array}{c}\text { Devizni } \\
\text { krediti (+) } \\
\text { depoziti }(-)\end{array} \\
\text { Saldo }\end{array}$} \\
\hline & Saldo* & Saldo** & Saldo* & Saldo** & & & \\
\hline \multicolumn{8}{|c|}{ Zagrebačka ili središnja hrvatska makroregija } \\
\hline Zagrebačka županija & -864 & -549 & 84 & 35 & -35 & 128 & 4.049 \\
\hline Krapinsko-zagorska županija & 42 & 17 & -8 & -27 & -8 & 2 & 863 \\
\hline Sisačko-moslavačka županija & 205 & -19 & II & $-3 I$ & -12 & 7 & 179 \\
\hline Karlovačka županija & 55 & $-\mathrm{I} 33$ & 4 & -18 & 15 & 3 & -36 \\
\hline Varaždinska županija & 223 & 218 & -2 & -43 & -19 & 44 & 303 \\
\hline Koprivničko-križevačka županija & 73 & -139 & 4 & -22 & -15 & 6 & 188 \\
\hline Bjelovarsko-bilogorska županija & $-3 \mathrm{I}$ & -200 & $\mathrm{I}$ & -24 & -12 & 23 & 79 \\
\hline Međimurska županija & 97 & 55 & -2 & -29 & -12 & 2 & -64 \\
\hline Ukupno bez Zagreba & -200 & -749 & 93 & -158 & -97 & $2 \mathrm{I} 3$ & I.I39 \\
\hline Grad Zagreb & -6.147 & -1.865 & I05 & 756 & -220 & 753 & 824 \\
\hline Zagrebačka makroregija ukupno & -6.347 & $-2.6 \mathrm{I} 4$ & 198 & 597 & $-3 \mathrm{I} 8$ & 967 & I.963 \\
\hline \multicolumn{8}{|l|}{ Osječka ili slavonska makroregija } \\
\hline Virovitičko-podravska županija & 49 & -60 & $-0,06$ & $-\mathrm{I} 8$ & -8 & I & 80 \\
\hline Požeško-slavonska županija & 33 & -70 & $-\mathrm{I}$ & -16 & -8 & $\mathrm{I}$ & 38 \\
\hline Brodsko-posavska županija & -23 & $-\mathrm{I} 55$ & 15 & -13 & -14 & 3 & II3 \\
\hline Osječko-baranjska županija & 29 & -466 & IO & -67 & -38 & I & 751 \\
\hline Vukovarsko-srijemska županija & -54 & -232 & I & -33 & $-\mathrm{I} 7$ & -8 & 217 \\
\hline Osječka makroregija ukupno & 33 & -984 & 26 & -147 & -85 & $-I$ & I.199 \\
\hline NUTS 2 Kontinentalna Hrvatska & -6.314 & -3.598 & 224 & 450 & -403 & 965 & 3.163 \\
\hline \multicolumn{8}{|c|}{ Riječka ili primorsko-goranska makroregija } \\
\hline Primorsko-goranska županija & $-3 I$ & -887 & I3I & 56 & 1.032 & 106 & $-\mathrm{I} 74$ \\
\hline Ličko-senjska županija & 5 & -125 & $-0,15$ & -13 & I67 & 4 & -2 \\
\hline Istarska županija & 15 & -269 & -4 & -48 & 2.123 & 55 & -349 \\
\hline Riječka makroregija ukupno & $-\mathrm{IO}$ & $-\mathrm{I} .28 \mathrm{I}$ & $\mathrm{I} 26$ & -5 & 3.322 & 165 & -525 \\
\hline \multicolumn{8}{|l|}{ Splitska ili dalmatinska makroregija } \\
\hline Zadarska županija & 25 & -345 & 47 & 37 & 773 & 12 & -126 \\
\hline Šibensko-kninska županija & 2 & -55 & IOO & 78 & 319 & $-2 I$ & 600 \\
\hline Splitsko-dalmatinska županija & -199 & $-84 \mathrm{I}$ & -45 & -IIO & I.075 & 46 & -1.329 \\
\hline Dubrovačko-neretvanska županija & -46 & -420 & 69 & 72 & 756 & 6 & -148 \\
\hline Splitska makroregija ukupno & $-2 \mathrm{I} 8$ & -1.662 & $\mathrm{I7I}$ & 76 & 2.923 & 43 & -1.002 \\
\hline NUTS 2 Jadranska Hrvatska & -228 & -2.943 & 297 & $7 \mathrm{I}$ & 6.245 & 208 & $-\mathrm{I} .527$ \\
\hline RH ukupno & $-6.54 \mathrm{I}$ & $-6.54 \mathrm{I}$ & $52 \mathrm{I}$ & $52 \mathrm{I}$ & 5.842 & I.I73 & I.636 \\
\hline
\end{tabular}

Pogled na salda podbilanci u tablici 5. proširuje spoznaju te preciznije ukazuje na potrebu i smjer djelovanja. U mozaiku pozitivnih i negativnih deviznih salda ima dovoljno elemenata da se o svakoj županiji ispiše zasebna studija. Posebno ako se kao analitički materijal upotrijebe i apsolutni iznosi pojedinih stavki prezentirani u tablicama na kraju rada.

Na ovom mjestu tek osnovni dojam. 
O robnoj razmjeni i razmjeni usluga s inozemstvom već je iz perspektive svodnih regionalnih bilanci ponešto kazano. U ovoj bilanci, jednako kao i kod salda usluga, promjena registracije uvoza s adrese poduzeća koja su realizirala uvoz robe i usluga na potencijalnu konačnu namjenu uvoza "prostrla” je negativna županijska salda $u$ hrvatski prostor. Devizna bilanca turizma bez pogovora je podijelila Hrvatsku na dva dijela. Stanovništvo i gospodarstvo Kontinentalne Hrvatske više troši na odlaske u inozemstvo nego prihoduju deviza od stranih turista. Saldo stranih investicija tek je u dvije županije negativan (Vukovarsko-srijemska i Šibensko-kninska). I konačno, saldo deviznih kredita i depozita. Nefinancijska društva iskazuju negativan saldo u svim županijama, a saldo kućanstava, i još više ukupan saldo kredita i depozita oba rezidenta još jednom upozorava na dvodjelnu deviznu i gospodarsku Hrvatsku.

\section{GRAFIKON 3.}

Saldo izvoza* (+) i uvoza* (-) po županijama 2012.

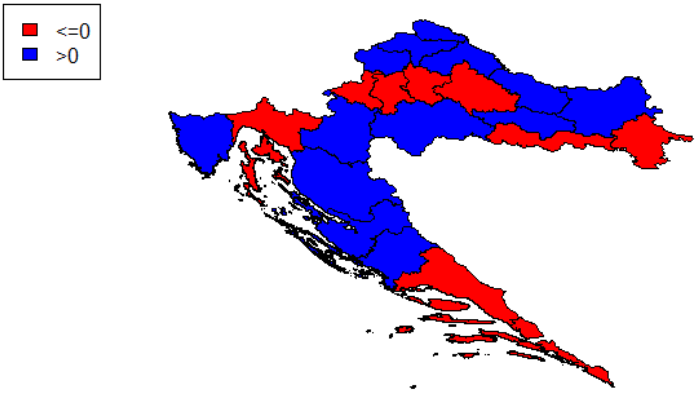

GRAFIKON 4.

Saldo izvoza* (+) i uvoza** (-) roba po županijama 2012.

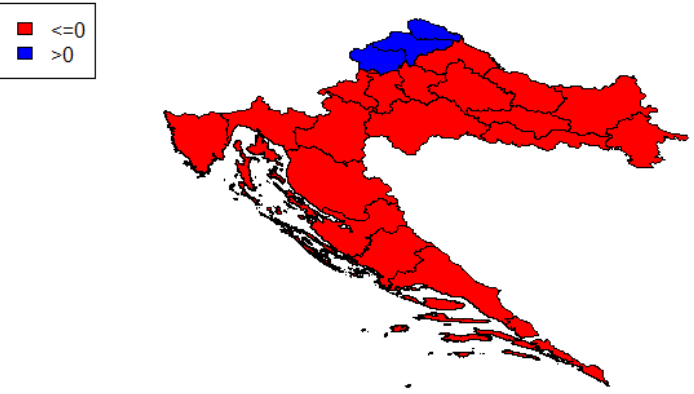


GRAFIKON 5 .

Saldo prihoda* (+) i rashoda* (-) usluga po županijama 2012.

므 $<>0$

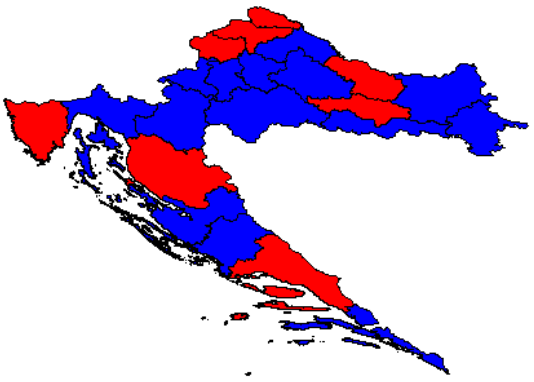

GRAFIKON 6.

Saldo prihoda*(+) i rashoda**(-) usluga po županijama 2012.
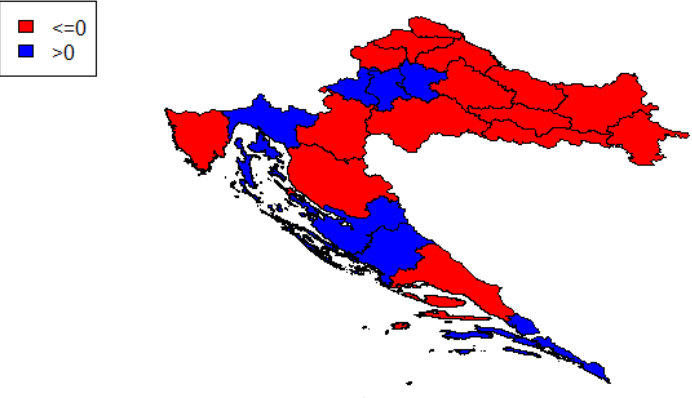

\section{GRAFIKON 7.}

Saldo deviznih prihoda (+) i rashoda (-) turizma po županijama 2012.

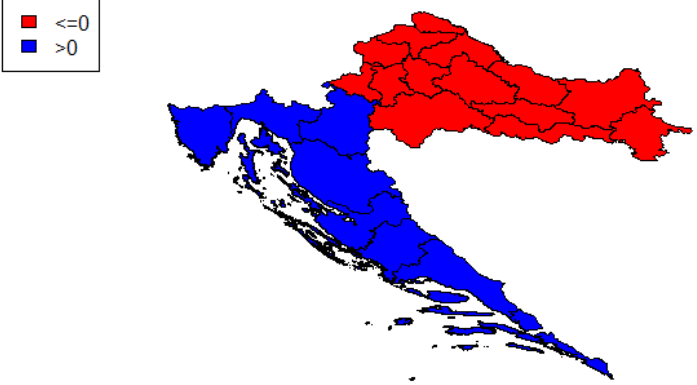


GRAFIKON 8.

Saldo izravnih ulaganja u (-) i iz (+) inozemstva po županijama 2012.

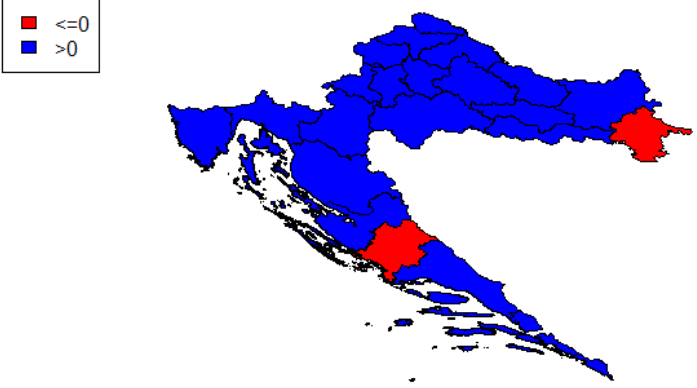

GRAFIKON 9.

Saldo deviznih kredita (+) i deviznih depozita (-) nefinancijskih društava po županijama 2012.

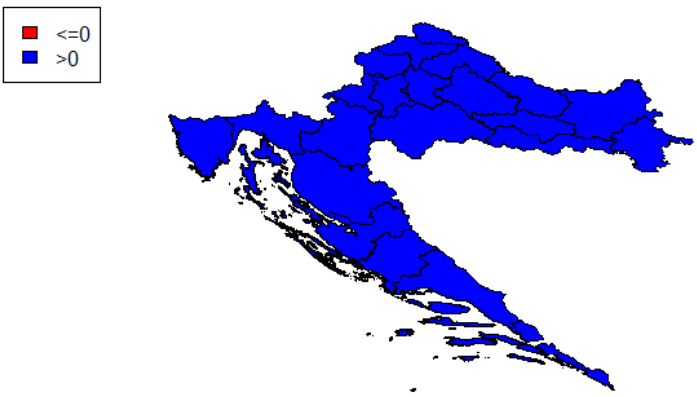

\section{GRAFIKON IO.}

Saldo deviznih kredita (+)i deviznih depozita (-) kućanstava po županijama 2012.
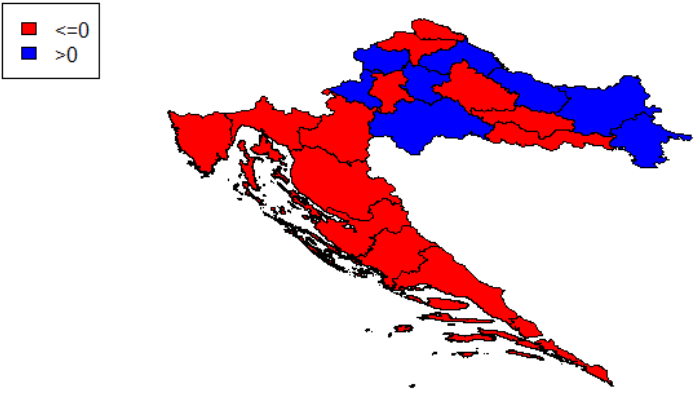


\section{GRAFIKON II.}

Saldo deviznih kredita (+) i deviznih depozita (-) nefinancijskih poduzeća i kućanstava po županijama 2012.

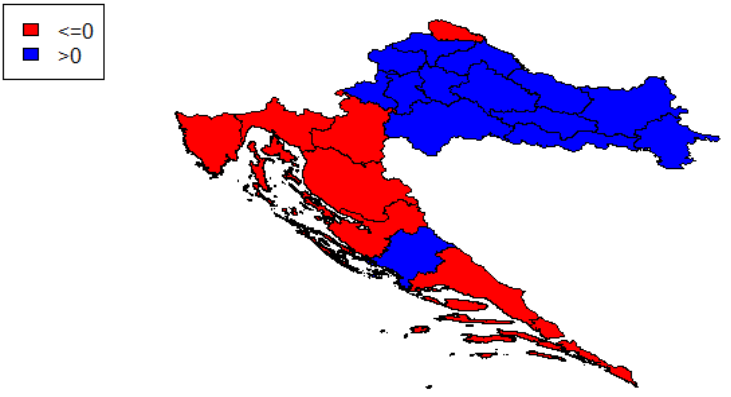

\section{CASE STUDY: IZLOŽENOST DEVIZNOM RIZIKU, ILI, UČINGI PROMJENE TEČAJA KUNE NA BDP REGIJA}

Svrha je regionalne platne bilance osigurati informacijsku bazu za ekonomsku analizu učinaka devizne aktivnosti regije na njene temeljne makroekonomske agregate. Zbog oskudne informacijske osnove hrvatske regionalne razine tek je nekoliko varijabli moguće dovesti u vezu. Koliko intenzivno neka ekonomska varijabla reagira na promjenu neke druge varijable koja je s njom u odnosu međuovisnosti pokazuje nam koeficijent elastičnosti. Raspolažući podatcima o deviznim transakcijama regija moguće je izračunati elastičnosti BDP-a na promjene tečaja domaće valute.

I8 U svakom udžbeniku makroekonomije stoji da, uz određene uvjete elastičnosti, devalvacija popravlja bilancu vanjske trgovine. Što se događa ako u analizu uključimo i ostale segmente platne bilance? Elementarna ekonomska logika govori nam o posljedicama deprecijacije (ili devalvacije) domaće valute na svakog pojedinog rezidenta (Babić, 2000.). Pođimo redom.

Slabljenje vrijednosti domaće valute nefinancijskim bi društvima, odmah nakon objave promijenjene tečajne liste, povećalo vrijednost inozemnih potraživanja i potraživanja ugovorenih uz valutnu klauzulu. Riječ je o povećanju prihoda vezanih uz devizne outpute na stranim i domaćim tržištima. Na drugoj strani, onoj obveza, za iznos tečajne promjene povećali bi se troškovi nabave repromaterijala i inozemne opreme, te troškovi kamata na devizne kredite i kredite s deviznom klauzulom. Svi potrebni podatci za izračun ovog učinka sadržani su u prethodno izloženim platnim bilancama regija.

Kućanstva u Hrvatskoj imaju više imovine od obveza, što u situaciji deprecijacije domaće valute rezultira pozitivnim efektima na imovinu ovog sektora u usporedbi s njegovim obvezama. Da su statističke okolnosti bile povoljnije (nisu uključene doznake iz inozemstva i inozemne mirovine) pozitiva ovog rezidenta $u$ izračunu bi bila još izraženija.

I financijski sektor je snažno involviran u deprecijacijsku temu. Devizni krediti i krediti s valutnom klauzulom bi za iznos deprecijacije poskupili. Otplatne rate bi se za isti iznos povećale. Istodobno, vlasnici deviznih depozita bi zahvaljivali guverneru središnje banke koji je odluku o deprecijaciji potpisao.

Opće države nema u regionalnim platnim bilancama, pa u izračunu koji slijedi nema ni efekata deprecijacije na ovaj sektor. Stoga, tek iz edukativnih razloga, treba napomenuti da kod ovog rezidenta 
dominiraju obveze inozemstvu (posebno vanjski dug) koje svaka deprecijacija, jer država pri svakoj otplati mora mijenjati kune, $\mathrm{u}$ istom postotku povećava.

\section{TABLICA 6.}

Utjecaj deprecijacije kune u odnosu na euro u postotku BDP-a regija 2012.

\begin{tabular}{|c|c|c|c|c|}
\hline \multirow{3}{*}{ NUTS 2, makroregija, županija } & \multicolumn{4}{|c|}{ Razlika u \% BDP-a } \\
\hline & \multicolumn{2}{|c|}{$\begin{array}{l}\text { Tečaj kuna/euro } \\
\text { 7,5172 } \rightarrow 7,5924 \text { (>1\%) }\end{array}$} & \multicolumn{2}{|c|}{$\begin{array}{c}\text { Tečaj kuna/euro } \\
7,5172 \rightarrow 8,2689(>10 \%)\end{array}$} \\
\hline & SRDB* $^{*}$ & PRDB $^{* *}$ & SRDB $^{*}$ & PRDB $^{* *}$ \\
\hline \multicolumn{5}{|c|}{ Zagrebačka ili središnja hrvatska makroregija } \\
\hline Zagrebačka županija & $-0,440$ & $-0,333$ & $-4,397$ & $-3,326$ \\
\hline Krapinsko-zagorska županija & $-0,07 \mathrm{I}$ & $-0,123$ & $-O, 7 \mathrm{II}$ & $-1,230$ \\
\hline Sisačko-moslavačka županija & 0,024 & $-0,169$ & 0,236 & $-1,694$ \\
\hline Karlovačka županija & O,II7 & $-O, I O I$ & $\mathrm{I}, \mathrm{I} 74$ & $-\mathrm{I}, \mathrm{OO} 5$ \\
\hline Varaždinska županija & $-0,039$ & $-0,07 \mathrm{I}$ & $-0,395$ & $-0,708$ \\
\hline Koprivničko-križevačka županija & -O,II4 & $-0,34 \mathrm{I}$ & $-\mathrm{I}, \mathrm{I} 44$ & $-3,4 \mathrm{IO}$ \\
\hline Bjelovarsko-bilogorska županija & $-\mathrm{O}, \mathrm{I} 2 \mathrm{I}$ & $-0,360$ & $-\mathrm{I}, 2 \mathrm{IO}$ & $-3,596$ \\
\hline Međimurska županija & $\mathrm{O}, \mathrm{I} 56$ & 0,084 & $\mathrm{I}, 558$ & $0,84 \mathrm{I}$ \\
\hline Ukupno bez Zagreba & $-\mathrm{O}, \mathrm{II} 4$ & $-0,194$ & $-\mathrm{I}, \mathrm{I} 38$ & $-1,945$ \\
\hline Grad Zagreb & $-0,43 \mathrm{I}$ & $-0,095$ & $-4,315$ & $-0,954$ \\
\hline Zagrebačka makroregija ukupno & $-0,303$ & $-\mathrm{O}, \mathrm{I} 35$ & $-3,033$ & $-I, 354$ \\
\hline \multicolumn{5}{|l|}{ Osječka ili slavonska makroregija } \\
\hline Virovitičko-podravska županija & $-0,075$ & $-0,319$ & $-0,747$ & $-3,191$ \\
\hline Požeško-slavonska županija & $-0,030$ & $-0,28 \mathrm{I}$ & $-0,297$ & $-2,8 \mathrm{I} 2$ \\
\hline Brodsko-posavska županija & $-0, I 43$ & $-0,3 \mathrm{I} 8$ & $-\mathrm{I}, 432$ & $-3,179$ \\
\hline Osječko-baranjska županija & $-0,305$ & $-0,538$ & $-3,052$ & $-5,383$ \\
\hline Vukovarsko-srijemska županija & $-0,277$ & $-0,476$ & $-2,769$ & $-4,76 I$ \\
\hline Osječka makroregija ukupno & $-0,226$ & $-0,446$ & $-2,263$ & $-4,456$ \\
\hline NUTS 2 Kontinentalna Hrvatska & $-0,289$ & -O,I9I & $-2,894$ & $-\mathrm{I}, 9 \mathrm{I} 4$ \\
\hline \multicolumn{5}{|c|}{ Riječka ili primorsko-goranska makroregija } \\
\hline Primorsko-goranska županija & 0,365 & O,I24 & 3,647 & $\mathrm{I}, 242$ \\
\hline Ličko-senjska županija & 0,457 & 0,088 & 4,575 & 0,875 \\
\hline Istarska županija & 0,964 & 0,840 & 9,642 & 8,397 \\
\hline Riječka makroregija ukupno & 0,599 & 0,395 & 5,989 & 3,954 \\
\hline \multicolumn{5}{|l|}{ Splitska ili dalmatinska makroregija } \\
\hline Zadarska županija & 0,704 & $0,43 \mathrm{I}$ & 7,038 & $4,3 \mathrm{I} 4$ \\
\hline Šibensko-kninska županija & $-0,236$ & $-0,330$ & $-2,356$ & $-3,304$ \\
\hline Splitsko-dalmatinska županija & 0,615 & $0,4 \mathrm{I} 8$ & $6, \mathrm{I} 5 \mathrm{I}$ & 4,179 \\
\hline Dubrovačko-neretvanska županija & 0,772 & 0,464 & 7,717 & 4,644 \\
\hline Splitska makroregija ukupno & 0,557 & 0,338 & 5,572 & 3,385 \\
\hline NUTS 2 Jadranska Hrvatska & 0,578 & 0,367 & 5,778 & 3,667 \\
\hline RH ukupno & -O,OI5 & $-0,015$ & $-0, I 46$ & $-0, I 46$ \\
\hline
\end{tabular}

U tablici 6 su rezultati dva izračuna pretpostavljene deprecijacije kune primijenjeni na regionalne platnobilančne uvjete 2012. To je i razlog startnog tečaja izračuna od 7,5172 kune za jedan euro, prosječnog u toj godini. U drugom i trećem stupcu tablice ukalkulirana je jednopostotna deprecijacija što ima značaj koeficijenta elastičnosti BDP-a na promjene tečaja domaće valute. U četvrtom i petom stupcu su rezultati za slučaj desetpostotne deprecijacije. Iako se ova dva posljednja stupca moglo ispustiti, učinjen je ustupak menadžerima izvoznih poduzeća koji, svake godine, uvijek iznova zahtijevaju otprilike toliku deprecijaciju. I ovdje su, kao i u prethodnim izračunima, rezultati iskazani za obje varijante regionalnih platnih bilanci dobivene različitim tretmanom alokacije uvoza roba i usluga.

U rezultatu, još jednom, ista priča. Pola države bi deprecijacijom zaradilo, a pola izgubilo. I to ne slučajnih pola županija disperziranih amo i tamo, već jasno zemljopisno (i gospodarski) grupiranih. 
Tek, da se potvrdi ona kako izuzetak potvrđuje pravilo, tu su Međimurska, jedina koja bi imala pozitivan efekt izražen u postotku svog BDP-a u Kontinentalnoj Hrvatskoj, i Šibensko-kninska županija, jedina s negativnim efektom u Jadranskoj Hrvatskoj.

\section{GRAFIKON I2.}

Pozitivni i negativni učinci pretpostavljene deprecijacije po županijama 2012.

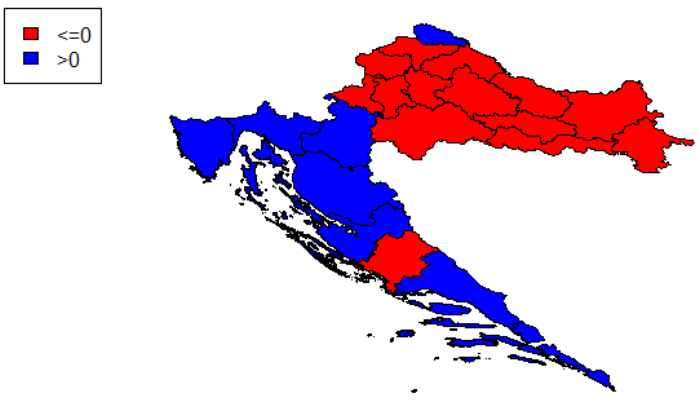

U kojoj bi mjeri ( $\mathrm{u}$ varijanti $\mathrm{PRDB}^{* *}$ ) potencijalna deprecijacija utjecala na već postojeće regionalne razlike razvijenosti, ako za trenutak iz analize ispustimo Grad Zagreb, pokazuju sljedeće brojke. U trinaest županija deprecijacijskih "gubitnika” 2012. je oko 49\% hrvatskih stanovnika ostvarivalo oko 35\% hrvatskog BDP-a. Na drugoj strani je sedam “dobitničkih” županija u kojima je 33\% stanovnika Hrvatske ostvarivalo oko $32 \%$ hrvatskog BDP-a. Dva su važna učinka deprecijacije na regionalne disparitete. Prvi, "boljestojeći” bi se dodatno udaljili od razvojno najslabijih, i drugi, promatramo li ih u cjelini, desetpostotnom bi deprecijacijom “boljestojeći” dostigli hrvatski BDP prosjek.

Rasprava o rezultatu svake pojedine županije "razvodnila” bi suštinu ove analize. Ali, za istaknuti je bar vodeće među potencijalnim "gubitnicima” i “dobitnicima“. U "S" varijanti regionalnih platnih bilanci najveći su "gubitnici” Zagrebačka županija, Grad Zagreb, Osječko-baranjska, Vukovarskosrijemska i Šibensko-kninska županija. U toj varijanti platnih bilanci dobitnice su sve jadranske županije osim Šibensko-kninske. U “P” varijanti pozitivni su manje pozitivni, negativni više negativni, jedino Grad Zagreb profitira.

Na kraju, važno je još jednom napomenuti, svi prethodni izračuni i zaključci vrijede ceteris paribus, dakle $u$ situaciji izoliranog utjecaja deviznih transakcija na gospodarski razvoj. Kako bi učinci deprecijacije utjecali ako bi se njen iznos, na primjer, u cijelosti, kroz cijene, uslijed visoke elastičnosti cijena prema tečaju, prelio na krajnje potrošače, ili, ako korisnici, hipotetski, kredite ne bi mogli otplaćivati, pitanja su na koja odgovori prelaze okvire ovog rada. 


\section{ZAKLJUČAK, ILI, TKO TO TAMO MISLI DA IZ RAKURSA DEVIZNE ZAVIČAJNOSTI TREBA ISPUSTITI REGIONALNU DIMENZIJU}

Sasvim je sigurno, sam spomen regionalnog aspekta u ekonomiji međunarodne razmjene budi sumnje $\mathrm{u}$ vjerodostojnost metodološkog aparata koji tom aspektu služi, a onda i u rezultate koji se na njemu temelje. Uostalom, i semantički je upitno nešto međunarodno, dakle između naroda, primijeniti na uže teritorijalne cjeline, sastavnice jednog naroda (i jedne ekonomije). Ako se tome pridoda i neupitna monetarna nacionalna cjelovitost, svaki trud, u izgradnji regionalne statističke i metodološke aparature koja bi pomogla dati odgovore na brojna pitanja o razini i kvaliteti uključenosti regije $\mathrm{u}$ međunarodne robne i devizne tokove, ili, na primjer, o utjecaju mjera monetarne politike na regionalne ekonomije, čini se uzaludan. Mnoge bi analize bilo moguće izraditi ako se posjeduje regionalne društvene račune $\mathrm{u}$ kojima se registrira razmjena regije s okolinom, kako domaćom tako i inozemnom. Međutim, analitičari regionalne ekonomije Hrvatske to ne mogu raditi iz prostog razloga jer se takvi računi u Hrvatskoj ne izrađuju.

Što, na primjer, ako analitičar baš hoće uzaludno trošiti vrijeme i uz to nastojati rezultate tog svog jalovog posla predočiti javnosti? Javnost u pravilu voli atraktivnosti. Poneku atrakciju, čak ako je temeljena na sumnjivom metodološkom okviru, može pronaći i u ovom radu. Znanstvena javnost, međutim, zahtijeva znanstvene argumente. Ta javnost prosuđuje i presuđuje ima li u nekom radu dovoljno čvrstih argumenata da ga može smatrati relevantnim.

Evo što se, u tom smislu, može pronaći na prethodnim stranicama ovog rada.

Prije svega, o stanju regionalne hrvatske gospodarske statistike koja se posljednjih šezdeset godina kretala putanjom krivulje normalne distribucije s vremenski točno određenim maksimumom. Kretala se uzlazno, kvantitativno i kvalitativno, do trenutka kada je objavljen prvi i posljednji regionalni statistički godišnjak (DSZ, 1994.). Od tada naovamo, sve je manje regionalnih statistika (osim demografske statistike), a onih publiciranih, koje bi mogle poslužiti u izradi regionalnih platnih bilanci nema. Stoga, implicitno, ovaj rad pledira za vraćanje regionalne (gospodarske) statistike javnosti, za publicirani regionalni iskorak DZS-a.

Drugo, o metodologiji izrade regionalne platne bilance. Za sastavljanje ovih bilanci korišten je obrazac nacionalne platne bilance s idejom da se njene stavke teritorijaliziraju, odnosno, rasprše po hrvatskim regionalnim jedinicama. U tom je smislu definirana "idealna” regionalna platna bilanca bez stavki opće države. Na putu od "idealne”, zbog nepostojanja svih potrebnih podataka, regionalne platne bilance transformirale su se u "objektivno moguće". Postale su sistematičan prikaz vrijednosti dostupnih ekonomskih transakcija regionalnih rezidenata koje su, bez obzira da li s inozemstvom ili s domaćim rezidentima, obavljene $u$ stranoj valuti (ili u kunama s deviznom klauzulom) $\mathrm{u}$ određenom razdoblju. Na taj način koncipirane, regionalne se platne bilance u svom značajnom dijelu treba smatrati deviznim bilancama. Konačan rezultat sraza teorije ("idealne" bilance) i statističke prakse ("objektivno moguće") su u radu predočene regionalne platne bilance u kojima se evidentira bilanca roba i usluga i bilanca kapitalnih i financijskih transakcija, dok je bilanca transfera i dohodaka, uslijed problema s podatcima, ispuštena. Još se jedna važna promjena dogodila na putu od nacionalnih prema regionalnim bilancama. Kriterij nacionalnih računa "domaće-inozemno" u predstavljenim regionalnim kratkoročnim bilancama kapitalnih i financijskih transakcija zamijenjen je kriterijem "devizno-kunsko" prema kojem su sve financijske transakcije regionalnih rezidenata $u$ devizama ili u kunama s deviznom klauzulom, dakle i one u zemlji i one u inozemstvu, sadržaj ovog segmenta 
regionalnih bilanci kapitalnih i financijskih transakcija. Dakle, ovaj rad eksplicitno nudi metodologiju izrade platnih bilanci (hrvatskih) regija.

Analiza podataka iz regionalnih platnih bilanci identificira značajne regionalne razlike kako $\mathrm{u}$ svodnim bilancama tako i u svakoj pojedinoj podbilanci. Međutim, u radu je istaknuto, te razlike ne moraju značiti da je neka županija ili regija bogatija ili razvijenija od drugih koje iskazuju lošije platnobilančne rezultate. Ono što se u radu naglašava je da različita razina županijske izloženosti deviznom riziku potencijalno zahtijeva selektivni pristup ekonomske politike.

Za ocjenu deviznog (a i ukupnog međunarodnog) položaja pojedinih regionalnih jedinica korištena su dva indikatora. Prvi, kvantificira uključenost regija u devizne transakcije i transakcije s deviznom klauzulom, a drugi, korišten u case study, koeficijent elastičnosti BDP-a u odnosu na tečaj kune. Bez obzira što prvi identificira snagu i rang uključenosti, a drugi graničnu promjenu varijable, i jedan i drugi, s pozicije devizne bilance, ukazuju na snažnu dvodijelnost hrvatskog gospodarskog prostora, već prepoznatu u postupku europskog dijeljenja Hrvatske na Kontinentalnu i Jadransku. U slučaju deprecijacije kune, gdje su devizne transakcije u odnosu na ostale ekonomske agregate tretirane ceteris paribus, dogodili bi se značajni regionalni “dobici” i "gubici”, koji bi, prema rezultatima ove analize, vodili sve većoj razvojnoj nejednakosti u prostoru Hrvatske. Atraktivnost dobivenih rezultata, bez obzira na teorijska i praktična ograničenja, ovaj rad pretvara u poziv za dodatna istraživanja utjecaja mjera ekonomske, posebno monetarne, politike na regionalni razvoj.

I to bi bilo to! Je li vrijedilo truda? Može li izneseno izdržati znanstvenu kritiku? Ako su odgovori na ova pitanja i niječni, autor je u veselju proveo tri istraživačka mjeseca. 


\section{DODATAK}

TABLICA AI.

Površina i stanouništvo RH-a po NUTS 2*, makroregijama** $i$ županijama u 2011.

\begin{tabular}{|c|c|c|c|c|c|}
\hline NUTS 2, makroregije* i županije Hrvatske & Površina $\left(\mathrm{km}^{2}\right)$ & $\%$ & Stanovništvo & $\%$ & $\begin{array}{l}\text { Gus. nas. } \\
\left(\mathrm{st} . / \mathrm{km}^{2}\right)\end{array}$ \\
\hline \multicolumn{6}{|l|}{ Zagrebačka ili srednja hrvatska makroregija } \\
\hline I Zagrebačka & 3.060 & $5,4 \mathrm{I}$ & 317.606 & $7,4 \mathrm{I}$ & IO3,8 \\
\hline II Krapinsko-zagorska & 1.229 & 2,17 & I32.892 & $3, \mathrm{IO}$ & IO8,I \\
\hline III Sisačko-moslavačka & 4.468 & 7,89 & 172.439 & $4, \mathrm{O} 2$ & 38,6 \\
\hline IV Karlovačka & 3.626 & $6,4 \mathrm{I}$ & I28.899 & $3, \mathrm{OI}$ & 35,5 \\
\hline V Varaždinska & I.262 & 2,23 & $\mathrm{I} 75.95 \mathrm{I}$ & 4, II & $\mathrm{I} 39,4$ \\
\hline VI Koprivničko-križevačka & I. 748 & 3,09 & II5.584 & 2,70 & $66, \mathrm{I}$ \\
\hline VII Bjelovarsko-bilogorska & 2.640 & 4,66 & II9.764 & 2,80 & 45,4 \\
\hline XX Međimurska & 729 & $\mathrm{I}, 29$ & II 3.804 & 2,66 & I56,I \\
\hline Ukupno & 18.762 & 33,15 & I.276.939 & 29,80 & $68, I$ \\
\hline Grad Zagreb & 64I & $\mathrm{I}, \mathrm{I} 3$ & 790.017 & $\mathrm{I} 8,44$ & I.232,5 \\
\hline Zagrebačka makroregija ukupno & 19.403 & 34,28 & 2.066 .956 & 48,24 & IO6,5 \\
\hline \multicolumn{6}{|l|}{ Osječka ili slavonska makroregija } \\
\hline X Virovitičko-podravska & 2.024 & 3,58 & 84.836 & $\mathrm{I}, 98$ & $4 I, 9$ \\
\hline XI Požeško-slavonska & I.823 & 3,22 & 78.034 & $\mathrm{I}, 82$ & 42,8 \\
\hline XII Brodsko-posavska & 2.030 & 3,59 & 158.575 & 3,70 & $78, \mathrm{I}$ \\
\hline XIV Osječko-baranjska & 4.155 & 7,34 & 305.032 & 7,12 & 73,4 \\
\hline XVI Vukovarsko-srijemska & 2.454 & 4,34 & I79.52I & 4,19 & 73,4 \\
\hline Osječka makroregija ukupno & $\mathrm{I} 2.486$ & 22,06 & 805.998 & $\mathrm{I} 8,8 \mathrm{I}$ & 64,5 \\
\hline NUTS 2 Kontinentalna Hrvatska & 3I.889 & 56,34 & 2.872 .954 & 67,05 & 90,09 \\
\hline \multicolumn{6}{|l|}{ Riječka ili primorsko-goranska makroregija } \\
\hline VIII Primorsko-goranska & 3.588 & 6,34 & 296.195 & $6,9 \mathrm{I}$ & 82,5 \\
\hline IX Ličko-senjska & 5.353 & 9,46 & 50.927 & I,I9 & 9,5 \\
\hline XVIII Istarska & $2.8 \mathrm{I} 3$ & 4,97 & 208.055 & 4,86 & 74,0 \\
\hline Riječka makroregija ukupno & II. 754 & 20,77 & 555.177 & $\mathrm{I} 2,96$ & 47,2 \\
\hline \multicolumn{6}{|l|}{ Splitska ili dalmatinska makroregija } \\
\hline XIII Zadarska & 3.646 & 6,44 & 170.017 & 3,97 & 46,6 \\
\hline XV Šibensko-kninska & 2.984 & 5,27 & IO9.375 & 2,55 & 36,6 \\
\hline XVII Splitsko-dalmatinska & 4.540 & 8,02 & 454.798 & IO,6I & $\mathrm{IOO}, 2$ \\
\hline XIX Dubrovačko-neretvanska & I.78I & $3, \mathrm{I} 5$ & $\mathrm{I} 22.568$ & 2,86 & 68,8 \\
\hline Splitska makroregija ukupno & I2.95I & 22,88 & 856.758 & 19,99 & $66, \mathrm{I}$ \\
\hline NUTS 2 Jadranska Hrvatska & 24.705 & 43,65 & I.4II.935 & 32,95 & 57,15 \\
\hline RH ukupno & 56.594 & 100,00 & 4.284 .889 & 100,00 & 75,0 \\
\hline
\end{tabular}

* Na temelju članka 43. Zakona o službenoj statistici NN (IO3/03, 75/O9, 52/I2) DZS određuje nacionalnu klasifikaciju prostornih jedinica. U kolovozu 2012. godine Europska komisija prihvatila je prijedlog podjele RH na dvije NUTS a regije, odnosno na Kontinentalnu i Jadransku Hrvatsku. Korištenje nove klasifikacije za potrebe Kohezijske politike započelo je po stupanju Hrvatske u članstvo EU, odnosno od I. srpnja 20I3. godine.

** Regionalizacija prema: Hrvatska enciklopedija, mrežno izdanje, Leksikografski zavod Miroslav Krleža, Zagreb, 20I3-2015.

Izvor: DZS, Popis stanovništva, kućanstava i stanova 20Ir. godine; DSZ, Statistički ljetopis 2014. 
TABLICA A2.

Bruto domaći proizvod RH-a po NUTS 2, makroregijama i županijama u 2012.

\begin{tabular}{|c|c|c|c|c|}
\hline NUTS 2, makroregije, županije & $\begin{array}{l}\text { BDP } \\
\text { mil. eura }\end{array}$ & $\%$ & $\begin{array}{l}\text { BDP po stanovniku } \\
\text { u eurima }\end{array}$ & $\begin{array}{c}\text { Hrvatska }=\text { Io } \\
\text { o }\end{array}$ \\
\hline \multicolumn{5}{|c|}{ Zagrebačka ili središnja hrvatska makroregija } \\
\hline Zagrebačka & $2.48 \mathrm{I}$ & 5,64 & $7.8 \mathrm{I} 2$ & $76, \mathrm{I}$ \\
\hline Krapinsko-zagorska & 823 & $\mathrm{I}, 87$ & 6.I93 & 60,4 \\
\hline Sisačko-moslavačka & I. 380 & 3,14 & 8.003 & 78,0 \\
\hline Karlovačka & 968 & 2,20 & $7.5 \mathrm{IO}$ & 73,2 \\
\hline Varaždinska & I.454 & $3,3 \mathrm{I}$ & 8.264 & 80,6 \\
\hline Koprivničko-križevačka & I.052 & 2,39 & 9.1O2 & 88,7 \\
\hline Bjelovarsko-bilogorska & $8 \mathrm{I} 3$ & 1,85 & 6.788 & 66,2 \\
\hline Međimurska & 958 & 2,18 & 8.418 & $82, \mathrm{I}$ \\
\hline Ukupno bez Zagreba & 9.929 & 22,59 & 7.776 & 75,8 \\
\hline Grad Zagreb & I4.675 & 33,38 & I8.576 & I8I,I \\
\hline Zagrebačka makroregija ukupno & 24.604 & 55,97 & II.9O3 & II6,O \\
\hline \multicolumn{5}{|l|}{ Osječka ili slavonska makroregija } \\
\hline Virovitičko-podravska & 520 & $\mathrm{I}, \mathrm{I} 8$ & 6.129 & 59,7 \\
\hline Požeško-slavonska & 468 & I,O6 & 5.997 & 58,5 \\
\hline Brodsko-posavska & 920 & 2,09 & 5.802 & 56,6 \\
\hline Osječko-baranjska & 2.452 & 5,58 & 8.039 & 78,4 \\
\hline Vukovarsko-srijemska & I.065 & 2,42 & 5.932 & 57,8 \\
\hline Osječka makroregija ukupno & 5.425 & $\mathrm{I} 2,34$ & $6.73 \mathrm{I}$ & 65,6 \\
\hline NUTS 2 Kontinentalna Hrvatska & 30.029 & $68,3 \mathrm{I}$ & 10.452 & IOI,9 \\
\hline \multicolumn{5}{|c|}{ Riječka ili primorsko-goranska makroregija } \\
\hline Primorsko-goranska & 3.873 & $8,8 \mathrm{I}$ & $\mathrm{I} 3.076$ & $\mathrm{I} 27,5$ \\
\hline Ličko-senjska & 388 & 0,88 & 7.619 & 74,3 \\
\hline Istarska & 2.633 & 5,99 & I2.655 & 123,4 \\
\hline Riječka makroregija ukupno & 6.894 & 15,68 & $\mathrm{I} 2.4 \mathrm{I} 8$ & I2I,O \\
\hline \multicolumn{5}{|l|}{ Splitska ili dalmatinska makroregija } \\
\hline Zadarska & I.398 & 3,18 & 8.223 & 80,2 \\
\hline Šibensko-kninska & 847 & 1,93 & 7.744 & 75,5 \\
\hline Splitsko-dalmatinska & 3.583 & 8,15 & 7.878 & 76,8 \\
\hline Dubrovačko-neretvanska & $\mathrm{I} .208$ & 2,75 & 9.856 & $96, \mathrm{I}$ \\
\hline Splitska makroregija ukupno & 7.036 & I6,OI & 8.212 & 80,0 \\
\hline NUTS 2 Jadranska Hrvatska & I3.930 & $3 I, 69$ & 9.866 & 96,2 \\
\hline RH ukupno & 43.959 & 100 & IO.259 & IOO,O \\
\hline
\end{tabular}

Izvor: DZS, Priopćenje broj 12.I.6. Bruto domaći proizvod za Republiku Hrvatsku, NKPJS - 2. razina i županije za razdoblje 2000.-2012. (ESA 20IO), Zagreb 13. ožujka 2015. 
TABLICA A3.

Robna razmjena RH-a s inozemstvom u mil. eura ${ }^{\dagger}$ - izvoz* i uvoz* po NUTS 2, makroregijama i županijama u $2 \mathrm{OI} 2$.

\begin{tabular}{|c|c|c|c|c|c|c|}
\hline NUTS 2, makroregije, županije & Izvoz* $^{*}$ & $\%$ & Uvoz $^{*}$ & $\%$ & Saldo & $\begin{array}{l}\text { Pokrivenost } \\
\text { (izvoz/uvoz }\end{array}$ \\
\hline \multicolumn{7}{|c|}{ Zagrebačka ili srednja hrvatska makroregija } \\
\hline Zagrebačka & $362, \mathrm{I}$ & 3,77 & I.226,2 & 7,59 & $-864, \mathrm{I}$ & 29,53 \\
\hline Krapinsko-zagorska & $3 \mathrm{I} 9,8$ & 3,33 & 278,2 & $\mathrm{I}, 72$ & $4 \mathrm{I}, 6$ & II4,95 \\
\hline Sisačko-moslavačka & $488, \mathrm{I}$ & 5,08 & 282,8 & 1,75 & 205,3 & 172,62 \\
\hline Karlovačka & 222,4 & 2,32 & $\mathrm{I} 67,4$ & $\mathrm{I}, \mathrm{O} 4$ & 55,0 & $\mathrm{I} 32,87$ \\
\hline Varaždinska & 752,3 & 7,83 & 529,5 & 3,28 & 222,8 & 142,07 \\
\hline Koprivničko-križevačka & 247,8 & 2,58 & $\mathrm{I} 74,6$ & $\mathrm{I}, 08$ & 73,2 & I4I,96 \\
\hline Bjelovarsko-bilogorska & 98,7 & $\mathrm{I}, \mathrm{O} 3$ & $\mathrm{I} 29,4$ & 0,80 & $-30,7$ & 76,30 \\
\hline Međimurska & 406,9 & 4,24 & 3IO,I & I,92 & 96,7 & $\mathrm{I} 3 \mathrm{I}, 2 \mathrm{O}$ \\
\hline Ukupno bez Zagreba & $2.898,0$ & 30,17 & $3.098,0$ & I9,I9 & $-200, \mathrm{I}$ & 93,54 \\
\hline Grad Zagreb & $3 \cdot 525,5$ & 36,70 & $9.672, \mathrm{I}$ & 59,90 & $-6.146,6$ & 36,45 \\
\hline Zagrebačka makroregija ukupno & $6.423,5$ & 66,87 & $\mathrm{I} 2.77 \mathrm{O}, \mathrm{I}$ & 79,09 & $-6.346,6$ & 50,30 \\
\hline \multicolumn{7}{|l|}{ Osječka ili slavonska makroregija } \\
\hline Virovitičko-podravska & I30,6 & I,36 & $8 \mathrm{I}, 7$ & $0,5 \mathrm{I}$ & 48,9 & $\mathrm{I} 59,8 \mathrm{O}$ \\
\hline Požeško-slavonska & IOI,5 & I,O6 & 69,0 & 0,43 & 32,5 & I47,II \\
\hline Brodsko-posavska & 182,8 & 1,90 & 205,8 & 1,27 & $-23,0$ & 88,82 \\
\hline Osječko-baranjska & 434,93 & 4,53 & $406, \mathrm{I}$ & 2,52 & 28,6 & 107,04 \\
\hline Vukovarsko-srijemska & I59,3 & $\mathrm{I}, 66$ & 213,4 & $\mathrm{I}, 32$ & $-54, \mathrm{I}$ & 74,66 \\
\hline Osječka makroregija ukupno & $1.008,8$ & IO,5O & 976,0 & 6,04 & 32,9 & IO3,37 \\
\hline NUTS 2 Kontinentalna Hrvatska & 7432,3 & 77,37 & $\mathrm{I} 3.746, \mathrm{O}$ & 85,13 & $-6.313,8$ & 54,07 \\
\hline \multicolumn{7}{|c|}{ Riječka ili primorsko-goranska makroregija } \\
\hline Primorsko-goranska & 535,3 & 5,57 & 565,9 & 3,50 & $-30,6$ & 94,59 \\
\hline Ličko-senjska & $\mathrm{I} 7,4$ & $\mathrm{O}, \mathrm{I} 8$ & $\mathrm{I} 2,2$ & 0,08 & 5,3 & 143,32 \\
\hline Istarska & 698,I & 7,27 & 682,7 & 4,23 & 15,5 & $\mathrm{IO} 2,27$ \\
\hline Riječka makroregija ukupno & I.250,9 & $\mathrm{I} 3, \mathrm{O} 2$ & $\mathrm{I} .260,8$ & $7,8 \mathrm{I}$ & $-9,8$ & 99,22 \\
\hline \multicolumn{7}{|l|}{ Splitska ili dalmatinska makroregija } \\
\hline Zadarska & $\mathrm{I} 68, \mathrm{I}$ & $\mathrm{I}, 75$ & 142,6 & 0,88 & 25,5 & $\mathrm{II} 7,86$ \\
\hline Šibensko-kninska & 255,7 & 2,66 & 253,3 & I,57 & 2,4 & IOO,94 \\
\hline Splitsko-dalmatinska & 475,2 & 4,95 & 674,4 & $4, \mathrm{I} 8$ & $-199,3$ & 70,45 \\
\hline Dubrovačko-neretvanska & 23,5 & 0,24 & 69,9 & 0,43 & $-46,4$ & 33,60 \\
\hline Splitska makroregija ukupno & 922,5 & 9,60 & I.I4O,3 & 7,06 & $-2 \mathrm{I} 7,8$ & 80,90 \\
\hline NUTS 2 Jadranska Hrvatska & $2.173,4$ & 22,62 & $2.4 \mathrm{OI}, \mathrm{I}$ & 14,87 & 227,7 & 90,52 \\
\hline Regije ukupno & $9.605,7$ & IOO,OO & I6.I47,I & IOO,OO & $-6.54 \mathrm{I}, 4$ & 59,49 \\
\hline Neraspoređeno & 23,0 & 0,24 & 67,3 & 0,42 & $-44,3$ & $34, \mathrm{I} 4$ \\
\hline RH ukupno & $9.628,6$ & 100,24 & I6.2I 4,4 & 100,42 & $-6.585,7$ & 59,38 \\
\hline
\end{tabular}

†Prosječan tečaj т eura u kunama 20I2. = 7,5172.

* Podatci po županijama dobiveni su na osnovi razvrstavanja poduzeća koja su realizirala izvoz i uvoz u županiju (općinu, grad) u kojoj su registrirana prema Registru poslovnih subjekata.

Izvor: DZS, Priopćenje broj 4.2.4., Robna razmjena Republike Hrvatske s inozemstvom po županijama, gradovima i općinama u 20I2. - Konačni podatci, Zagreb, I3. lipnja zoI3. 
TABLICA A4.

Robna razmjena RH-a s inozemstvom u mil. eura ${ }^{\dagger}-i z v o z^{*} i$ uvoz**, NUTS 2, makroregije i županije u 2012.

\begin{tabular}{|c|c|c|c|c|c|c|}
\hline NUTS 2, makroregije, županije & Izvoz* & $\%$ & Uvoz $^{* *}$ & $\%$ & Saldo & $\begin{array}{c}\text { Pokrivenost } \\
\text { (izvoz/uvoz) }\end{array}$ \\
\hline \multicolumn{7}{|c|}{ Zagrebačka ili srednja hrvatska makroregija } \\
\hline Zagrebačka & $362, \mathrm{I}$ & 3,77 & 9II,3 & 5,64 & $-549,3$ & 39,73 \\
\hline Krapinsko-zagorska & 319,8 & 3,33 & 302,3 & $\mathrm{I}, 87$ & $\mathrm{I} 7,5$ & 105,78 \\
\hline Sisačko-moslavačka & $488, \mathrm{I}$ & 5,08 & 506,9 & $3, \mathrm{I} 4$ & $-\mathrm{I} 8,8$ & 96,29 \\
\hline Karlovačka & 222,4 & 2,32 & 355,6 & 2,20 & $-\mathrm{I} 33,2$ & 62,54 \\
\hline Varaždinska & 752,3 & 7,83 & $534, \mathrm{I}$ & $3,3 \mathrm{I}$ & $2 \mathrm{I} 8,2$ & 140,85 \\
\hline Koprivničko-križevačka & 247,8 & 2,58 & 386,4 & 2,39 & $-138,6$ & 64,13 \\
\hline Bjelovarsko-bilogorska & 98,7 & I,O3 & 298,6 & $\mathrm{I}, 85$ & $-199,9$ & 33,05 \\
\hline Međimurska & 406,9 & 4,24 & $35 \mathrm{I}, 9$ & $2, \mathrm{I} 8$ & 55,0 & II 5,62 \\
\hline Ukupno bez Zagreba & $2.898,0$ & 30,17 & $3.647, \mathrm{I}$ & 22,59 & $-749,2$ & 79,46 \\
\hline Grad Zagreb & $3.525,5$ & 36,70 & $5 \cdot 390,5$ & 33,38 & $-\mathrm{I} .864, \mathrm{O}$ & 65,40 \\
\hline Zagrebačka makroregija ukupno & $6.423,5$ & 66,87 & $9.037,6$ & 55,97 & $-2.6 \mathrm{I} 4, \mathrm{I}$ & 71,07 \\
\hline \multicolumn{7}{|l|}{ Osječka ili slavonska makroregija } \\
\hline Virovitičko-podravska & I30,6 & $\mathrm{I}, 36$ & I9I,O & $\mathrm{I}, \mathrm{I} 8$ & $-60,4$ & 68,35 \\
\hline Požeško-slavonska & IOI,5 & I,O6 & I7I,9 & I,06 & $-70,4$ & 59,06 \\
\hline Brodsko-posavska & 182,8 & $\mathrm{I}, 90$ & 337,9 & 2,09 & $-I 55,2$ & 54,08 \\
\hline Osječko-baranjska & 434,9 & 4,53 & 900,7 & 5,58 & $-466,0$ & 48,26 \\
\hline Vukovarsko-srijemska & 159,3 & I,66 & 391,2 & 2,42 & $-23 I, 9$ & 40,72 \\
\hline Osječka makroregija ukupno & $1.008,8$ & IO,50 & I.992,7 & $\mathrm{I} 2,34$ & $-983,9$ & 50,63 \\
\hline NUTS 2 Kontinentalna Hrvatska & 7432,3 & 77,37 & II.O3O,3 & $68,3 \mathrm{I}$ & $-3.598,0$ & 67,38 \\
\hline \multicolumn{7}{|c|}{ Riječka ili primorsko-goranska makroregija } \\
\hline Primorsko-goranska & 535,3 & 5,57 & I.422,6 & $8,8 \mathrm{I}$ & $-887,3$ & 37,63 \\
\hline Ličko-senjska & $\mathrm{I} 7,4$ & $\mathrm{O}, \mathrm{I} 8$ & 142,5 & 0,88 & $-\mathrm{I} 25, \mathrm{I}$ & 12,24 \\
\hline Istarska & $698, \mathrm{I}$ & 7,27 & 967,2 & 5,99 & $-269,0$ & 72,18 \\
\hline Riječka makroregija ukupno & $1.250,9$ & $\mathrm{I} 3, \mathrm{O} 2$ & $2.532,3$ & I5,68 & $-\mathrm{I} .28 \mathrm{I}, 4$ & 49,40 \\
\hline \multicolumn{7}{|l|}{ Splitska ili dalmatinska makroregija } \\
\hline Zadarska & $\mathrm{I} 68, \mathrm{I}$ & $\mathrm{I}, 75$ & $5 \mathrm{I} 3,5$ & 3,18 & $-345,4$ & 32,73 \\
\hline Šibensko-kninska & 255,7 & 2,66 & 3II,I & $\mathrm{I}, 93$ & $-55,4$ & 82,20 \\
\hline Splitsko-dalmatinska & 475,2 & 4,95 & I.3I6,I & $8, \mathrm{I5}$ & $-840,9$ & 36, IO \\
\hline Dubrovačko-neretvanska & 23,5 & 0,24 & 443,7 & 2,75 & $-420,2$ & 5,29 \\
\hline Splitska makroregija ukupno & 922,5 & 9,60 & $2.584,5$ & I6,OI & $-1.662,0$ & 35,69 \\
\hline NUTS 2 Jadranska Hrvatska & $2.173,4$ & 22,62 & $5 . I I 6,8$ & 31,69 & $-2.943,4$ & 42,48 \\
\hline Makroregije ukupno & $9.605,7$ & IOO,OO & I6.I47,I & IOO & $-6.54 \mathrm{I}, 4$ & 59,49 \\
\hline Neraspoređeno & 23,0 & 0,24 & 67,3 & 0,42 & $-44,3$ & $34, \mathrm{I} 4$ \\
\hline RH ukupno & $9.628,6$ & 100,24 & I6.2I 4,4 & 100,42 & $-6.585,7$ & 59,38 \\
\hline
\end{tabular}

tProsječan tečaj I eura u kunama 2012. = 7,5172.

* Izvoz: Podatci po županijama dobiveni su na osnovi razvrstavanja poduzeća koja su realizirala izvoz u županiju (općinu, grad) u kojoj su registrirana prema Registru poslovnih subjekata.

** Uvoz: Procjena uvoza po županijama dobivena je na način da je ukupan uvoz RH-a raspodijeljen prema županijskoj strukturi BDP-a.

Izvor: DZS, Priopćenje broj 4.2.4., Robna razmjena Republike Hrvatske s inozemstvom po županijama, gradovima i općinama u 20I2. - Konačni podatci, Zagreb, 13. lipnja 2013. 
TABLICA A5.

Razmjena usluga RH-a s inozemstvom u mil. eurat - prihodi* i rashodi*, NUTS 2, makroregije i županije u $2 \mathrm{OI} 2$.

\begin{tabular}{|c|c|c|c|c|c|}
\hline NUTS 2, makroregije, županije & Prihod & $\%$ & Rashod & $\%$ & Saldo \\
\hline \multicolumn{6}{|c|}{ Zagrebačka ili srednja hrvatska makroregija } \\
\hline Zagrebačka & $\mathrm{I} 2 \mathrm{O}, 6$ & 5,94 & $36, I$ & 2,39 & 84,4 \\
\hline Krapinsko-zagorska & I,6 & 0,08 & 9,7 & 0,64 & $-8, \mathrm{I}$ \\
\hline Sisačko-moslavačka & $\mathrm{I} 6,2$ & $\mathrm{o}, 8 \mathrm{O}$ & 5,3 & 0,35 & II,O \\
\hline Karlovačka & $\mathrm{I} 5, \mathrm{O}$ & 0,74 & IO,5 & 0,70 & 4,4 \\
\hline Varaždinska & 7,2 & 0,36 & 8,9 & 0,59 & $-\mathrm{I}, 7$ \\
\hline Koprivničko-križevačka & $\mathrm{I} 4, \mathrm{O}$ & 0,69 & 9,7 & 0,64 & 4,3 \\
\hline Bjelovarsko-bilogorska & 4,0 & 0,20 & 3,2 & $\mathrm{O}, 2 \mathrm{I}$ & 0,9 \\
\hline Međimurska & 4,2 & $0,2 \mathrm{I}$ & 6,I & 0,40 & $-1,9$ \\
\hline Ukupno bez Zagreba & $\mathrm{I} 82,8$ & 9,00 & 89,4 & 5,92 & 93,4 \\
\hline Grad Zagreb & I.259,7 & $62, \mathrm{OI}$ & I.I54,7 & 76,46 & IO5,O \\
\hline Zagrebačka makroregija ukupno & I. 442,5 & $7 \mathrm{I}, \mathrm{OI}$ & I.244,I & 82,38 & I98,4 \\
\hline \multicolumn{6}{|l|}{ Osječka ili slavonska makroregija } \\
\hline Virovitičko-podravska & $\mathrm{O}$ & $\mathrm{O}, \mathrm{OO}$ & $\mathrm{O}, \mathrm{I}$ & $\mathrm{O}, \mathrm{OO}$ & $-\mathrm{O}, \mathrm{I}$ \\
\hline Požeško-slavonska & O,I & O,OI & $\mathrm{I}, 2$ & 0,08 & $-\mathrm{I}, \mathrm{I}$ \\
\hline Brodsko-posavska & $\mathrm{I} 8,4$ & O,9I & 3,0 & 0,20 & 15,4 \\
\hline Osječko-baranjska & 17,4 & 0,86 & 7,1 & 0,47 & 10,3 \\
\hline Vukovarsko-srijemska & 3,5 & $\mathrm{O}, \mathrm{I7}$ & 2,2 & $\mathrm{O}, \mathrm{I} 4$ & $\mathrm{I}, 3$ \\
\hline Osječka makroregija ukupno & 39,4 & I,94 & $\mathrm{I} 3,6$ & 0,90 & 25,8 \\
\hline NUTS 2 Kontinentalna Hrvatska & I.482,O & 72,95 & I. 257,7 & 83,28 & 224,2 \\
\hline \multicolumn{6}{|c|}{ Riječka ili primorsko-goranska makroregija } \\
\hline Primorsko-goranska & I89,0 & 9,30 & 58,2 & 3,85 & $\mathrm{I} 3 \mathrm{O}, 8$ \\
\hline Ličko-senjska & O,OOI & 0,00 & 0,2 & $\mathrm{O}, \mathrm{OI}$ & $-0,2$ \\
\hline Istarska & 42,7 & 2,10 & 47,0 & 3,II & $-4,3$ \\
\hline Riječka makroregija ukupno & $23 \mathrm{I}, 7$ & II,4O & $\mathrm{IO} 5,4$ & 6,98 & $\mathrm{I} 26,3$ \\
\hline \multicolumn{6}{|l|}{ Splitska ili dalmatinska makroregija } \\
\hline Zadarska & 85,4 & 4,20 & 38,2 & 2,53 & $47, \mathrm{I}$ \\
\hline Šibensko-kninska & I06,6 & 5,25 & 6,6 & 0,44 & IOO,O \\
\hline Splitsko-dalmatinska & $\mathrm{I} 2,6$ & 0,62 & $58, \mathrm{I}$ & 3,84 & $-45,4$ \\
\hline Dubrovačko-neretvanska & II3,3 & 5,58 & 44,2 & 2,93 & 69,I \\
\hline Splitska makroregija ukupno & 317,9 & 15,65 & $\mathrm{I} 47, \mathrm{I}$ & 9,74 & 170,8 \\
\hline NUTS 2 Jadranska Hrvatska & 549,6 & 27,05 & 252,5 & $\mathrm{I} 6,72$ & 297,2 \\
\hline RH usluge bez turizma & $2.03 I, 6$ & IOO,OO & $1.5 \mathrm{IO}, 2$ & IOO,OO & 521,4 \\
\hline Nepoznata županija (turizam)** & $7.609,9$ & 374,58 & I.6II,4 & IO6,70 & $5.998,6$ \\
\hline RH ukupno & $9.64 \mathrm{I}, 5$ & 474,58 & 3.I2I,6 & 206,70 & $6.520,0$ \\
\hline
\end{tabular}

†Prosječan tečaj I eura u kunama 2012. = 7,5172.

* Podatci po županijama dobiveni su na osnovi razvrstavanja poduzeća koja su realizirala prihode i rashode u županiju (općinu, grad) u kojoj su registrirana prema Registru poslovnih subjekata.

** Stavka Nepoznata županija odnosi se na dio usluga za koje nije moguće odrediti županiju, a u najvećem dijelu se odnosi na usluge putovanja (turizam) za koje metoda procjene ne omogućava geografsku podjelu rashoda.

Izvor: HNB, Sektor statistike, srpanj 2015. Izrađeno u skladu s Metodologijom za razmjenu usluga s inozemstvom prema: http://www.hnb.hr/statistika/razmjena-usluga-inozemstvom/h-obuhvat-metodologija.pdf. 
TABLICA A6.

Razmjena usluga RH-a s inozemstvom u mil. eura - prihodi* i rashodi**, NUTS 2, makroregije i županije u 2012.

\begin{tabular}{|c|c|c|c|c|c|}
\hline NUTS 2, makroregije, županije & Prihod & $\%$ & Rashod & $\%$ & Saldo \\
\hline \multicolumn{6}{|c|}{ Zagrebačka ili srednja hrvatska makroregija } \\
\hline Zagrebačka & $\mathrm{I} 2 \mathrm{O}, 6$ & 5,94 & 85,2 & 5,64 & 35,3 \\
\hline Krapinsko-zagorska & $\mathrm{I}, 7$ & 0,08 & 28,3 & $\mathrm{I}, 87$ & $-26,6$ \\
\hline Sisačko-moslavačka & $\mathrm{I} 6,2$ & 0,80 & 47,4 & $3, \mathrm{I} 4$ & $-3 I, 2$ \\
\hline Karlovačka & $15, \mathrm{O}$ & 0,74 & 33,3 & 2,20 & $-18,3$ \\
\hline Varaždinska & 7,2 & 0,36 & 50,0 & $3,3 \mathrm{I}$ & $-42,7$ \\
\hline Koprivničko-križevačka & $\mathrm{I} 4, \mathrm{O}$ & 0,69 & $36, \mathrm{I}$ & 2,39 & $-22,2$ \\
\hline Bjelovarsko-bilogorska & 4,0 & 0,20 & 27,9 & $\mathrm{I}, 85$ & $-23,9$ \\
\hline Međimurska & 4,2 & $0,2 \mathrm{I}$ & 32,9 & 2,18 & $-28,7$ \\
\hline Ukupno bez Zagreba & $\mathrm{I} 82,8$ & $9, \mathrm{OO}$ & 34I,I & 22,59 & $-158,3$ \\
\hline Grad Zagreb & $\mathrm{I} .259,7$ & $62, \mathrm{OI}$ & $5 \mathrm{O} 4,2$ & 33,38 & 755,6 \\
\hline Zagrebačka makroregija ukupno & $1.442,5$ & $7 \mathrm{I}, \mathrm{OI}$ & 845,3 & 55,97 & 597,3 \\
\hline \multicolumn{6}{|l|}{ Osječka ili slavonska makroregija } \\
\hline Virovitičko-podravska & $\mathrm{O}$ & $\mathrm{O}$ & 17,9 & $\mathrm{I}, \mathrm{I} 8$ & $-17,9$ \\
\hline Požeško-slavonska & $\mathrm{O}, \mathrm{I}$ & O,OI & I6,I & I,06 & $-16,0$ \\
\hline Brodsko-posavska & $\mathrm{I} 8,4$ & $0,9 \mathrm{I}$ & $3 I, 6$ & 2,09 & $-\mathrm{I} 3,2$ \\
\hline Osječko-baranjska & $\mathrm{I} 7,4 \mathrm{I}$ & 0,86 & 84,2 & 5,58 & $-66,8$ \\
\hline Vukovarsko-srijemska & 3,5 & $\mathrm{O}, \mathrm{I7}$ & 36,6 & 2,42 & $-33, \mathrm{I}$ \\
\hline Osječka makroregija ukupno & 39,4 & $\mathrm{I}, 94$ & $\mathrm{I} 86,4$ & $\mathrm{I} 2,34$ & $-146,9$ \\
\hline NUTS 2 Kontinentalna Hrvatska & $\mathrm{I} .482, \mathrm{O}$ & 72,95 & I.O3I,6 & $68,3 \mathrm{I}$ & 450,3 \\
\hline \multicolumn{6}{|c|}{ Riječka ili primorsko-goranska makroregija } \\
\hline Primorsko-goranska & $\mathrm{I} 89, \mathrm{O}$ & 9,30 & I33,I & $8,8 \mathrm{I}$ & 55,9 \\
\hline Ličko-senjska & O,OOI & $\mathrm{O}, \mathrm{OO}$ & $\mathrm{I} 3,3$ & $\mathrm{O}, 88$ & $-\mathrm{I} 3,3$ \\
\hline Istarska & 42,7 & $2, \mathrm{IO}$ & 90,5 & 5,99 & $-47,7$ \\
\hline Riječka makroregija ukupno & $23 \mathrm{I}, 7$ & II,4O & 236,8 & 15,68 & $-5,2$ \\
\hline \multicolumn{6}{|l|}{ Splitska ili dalmatinska makroregija } \\
\hline Zadarska & 85,4 & 4,20 & 48,0 & $3, \mathrm{I} 8$ & 37,3 \\
\hline Šibensko-kninska & IO6,6 & 5,25 & 29,I & I,93 & 77,5 \\
\hline Splitsko-dalmatinska & $\mathrm{I} 2,6$ & 0,62 & I23,I & 8,15 & $-\mathrm{IIO}, 5$ \\
\hline Dubrovačko-neretvanska & II3,3 & 5,58 & $4 \mathrm{I}, 5$ & 2,75 & 7I,8 \\
\hline Splitska makroregija ukupno & 317,9 & 15,65 & 241,7 & I6,OI & 76,2 \\
\hline NUTS 2 Jadranska Hrvatska & 549,6 & 27,05 & 478,6 & $3 \mathrm{I}, 69$ & 7I,I \\
\hline RH usluge bez turizma & $2.031,6$ & IOO,OO & $15 \mathrm{IO}, 2$ & IOO,OO & 521,4 \\
\hline Nepoznata županija (turizam) ${ }^{* * *}$ & $7.609,9$ & 374,58 & I6II,4 & IO6,70 & $5 \cdot 998,6$ \\
\hline RH ukupno & $9.64 I, 5$ & 474,58 & 3I2I,6 & 206,70 & $6.520,0$ \\
\hline
\end{tabular}

†Prosječan tečaj I eura u kunama 2012. = 7,5172.

** Procjena rashoda po županijama dobivena je na način da je ukupan rashod usluga RH-a raspodijeljen prema županijskoj strukturi BDP-a.

*** Stavka Nepoznata županija odnosi se na dio usluga za koje nije moguće odrediti županiju, a u najvećem dijelu se odnosi na usluge putovanja (turizam) za koje metoda procjene ne omogućava geografsku podjelu rashoda.

Izvor: HNB, Sektor statistike, srpanj 2015. Izrađeno u skladu s Metodologijom za razmjenu usluga s inozemstvom prema: http://www.hnb.hr/statistika/razmjena-usluga-inozemstvom/h-obuhvat-metodologija.pdf. 
TABLICA A7.

Devizni prihod od turizma 20I2. u mil. eura†, procjena po NUTS 2, makroregijama i županijama

\begin{tabular}{|c|c|c|c|c|}
\hline NUTS 2, makroregija, županija & $\begin{array}{c}\text { Dnevna } \\
\text { potrošnja }\end{array}$ & $\begin{array}{l}\text { Strana noćenja u } \\
\text { komercijalnom } \\
\text { smještaju }\end{array}$ & $\%$ & $\begin{array}{l}\text { Devizni } \\
\text { prihod }\end{array}$ \\
\hline \multicolumn{5}{|c|}{ Zagrebačka ili središnja hrvatska makroregija } \\
\hline Zagrebačka & 53,77 & $\mathrm{I}, 8$ & 0,05 & 3,2 \\
\hline Krapinsko-zagorska & 53,77 & 2,5 & 0,06 & 4,4 \\
\hline Sisačko-moslavačka & 53,77 & $\mathrm{I}, 3$ & 0,03 & 2,2 \\
\hline Karlovačka & 53,77 & $\mathrm{I} 4, \mathrm{O}$ & 0,36 & 24,8 \\
\hline Varaždinska & 53,77 & $2, \mathrm{I}$ & 0,06 & 3,8 \\
\hline Koprivničko-križevačka & 53,77 & 0,5 & O,OI & 0,8 \\
\hline Bjelovarsko-bilogorska & 53,77 & 0,5 & O,OI & 0,8 \\
\hline Međimurska & 53,77 & $\mathrm{I}, 8$ & 0,05 & 3,2 \\
\hline Ukupno bez Zagreba & 53,77 & 24,4 & 0,63 & 43,2 \\
\hline Grad Zagreb & IO4,86 & IOI,I & $2,6 \mathrm{I}$ & 179,2 \\
\hline Zagrebačka makroregija ukupno & 88,52 & $\mathrm{I} 25,4$ & 3,24 & 222,4 \\
\hline \multicolumn{5}{|l|}{ Osječka ili slavonska makroregija } \\
\hline Virovitičko-podravska & 53,77 & 0,4 & $\mathrm{O}, \mathrm{OI}$ & 0,7 \\
\hline Požeško-slavonska & 53,77 & 0,3 & O,OI & 0,5 \\
\hline Brodsko-posavska & 53,77 & 0,9 & 0,02 & $\mathrm{I}, 6$ \\
\hline Osječko-baranjska & 53,77 & 2,5 & 0,06 & 4,4 \\
\hline Vukovarsko-srijemska & 53,77 & $\mathrm{I}, \mathrm{O}$ & 0,03 & $\mathrm{I}, 8$ \\
\hline Osječka makroregija ukupno & 53,77 & 5,0 & $\mathrm{O}, \mathrm{I3}$ & 8,9 \\
\hline NUTS 2 Kontinentalna Hrvatska & 86,36 & 130,5 & 3,37 & $23 \mathrm{I}, 4$ \\
\hline \multicolumn{5}{|c|}{ Riječka ili primorsko-goranska makroregija } \\
\hline Primorsko-goranska & 57,55 & 624,3 & $\mathrm{I6}, \mathrm{I} 4$ & I.IO7,O \\
\hline Ličko-senjska & 56,18 & 96,4 & 2,49 & I7I,O \\
\hline Istarska & 63,79 & I.226,I & $3 \mathrm{I}, 7 \mathrm{O}$ & 2.I74,I \\
\hline Riječka makroregija ukupno & 61,25 & I.946,8 & 50,33 & $3.452, \mathrm{I}$ \\
\hline \multicolumn{5}{|l|}{ Splitska ili dalmatinska makroregija } \\
\hline Zadarska & 78,04 & 464,2 & $\mathrm{I} 2, \mathrm{OO}$ & $823, \mathrm{I}$ \\
\hline Šibensko-kninska & 53,77 & 197,2 & 5,IO & 350,0 \\
\hline Splitsko-dalmatinska & 69,64 & 678,5 & 17,54 & $\mathrm{I} .2 \mathrm{O} 3,2$ \\
\hline Dubrovačko-neretvanska & 92,63 & 450,7 & II,65 & 799,2 \\
\hline Splitska makroregija ukupno & 73,92 & I.790,7 & 46,30 & $3.175,2$ \\
\hline NUTS 2 Jadranska Hrvatska & 66,73 & $3.737,5$ & 96,63 & $6.627,3$ \\
\hline RH ukupno & 67,24 & $3.868, \mathrm{O}$ & IOO & $6.858,7$ \\
\hline
\end{tabular}

tProsječan tečaj I eura u kunama 2012. = 7,5172.

Izvor:

I. Noćenja stranih turista po županijama DZS, Statistička izvješća I49I/20I3, tablica 2.I2. Postelje, dolasci i noćenja turista po županijama, gradovima $i$ općinama u 2012., str. 6I-68.

2. Prosječni dnevni izdaci turista

2.I. Institut za turizam, Tomas 20I2., Stavovi i potrošnja turista u Hrvatskoj, tablica B27. Prosječni dnevni izdaci turista (u komercijalnom smještaju) u eurima prema županijama.

2.2. Za Grad Zagreb: Institut za turizam, Tomas 20I4., Stavovi i potrošnja turista i posjetitelja Zagreba, Zagreb 20I3., str. 4I-43.

2.3. Za županije: Zagrebačka, Krapinsko-zagorska, Sisačko-moslavačka, Karlovačka, Varaždinska, Koprivničko-križevačka, Bjelovarsko-bilogorska, Virovitičko-podravska, Požeško-slavonska, Brodsko-posavska, Osječko-baranjska, Vukovarska i Međimurska, procjena na razini najniže dnevne potrošnje Instituta za turizam.

3. Platna bilanca, DZS, Statistički ljetopis 20I4., tab. 22-II, Platna bilanca Republike Hrvatske, str. 407. 
TABLICA A8.

Turistička aktivnost domaćeg stanovništva u 2012. - putovanja u inozemstvo

Procjena po NUTS 2, makroregijama i županijama u mil. eura

\begin{tabular}{|c|c|c|c|}
\hline NUTS 2, makroregija, županija & Poslovna & Privatna & $\begin{array}{c}\text { Putovanja u } \\
\text { inozemstvo } \\
\text { domaćeg stanovništva }\end{array}$ \\
\hline \multicolumn{4}{|c|}{ Zagrebačka ili središnja hrvatska makroregija } \\
\hline Zagrebačka & 21,7 & $\mathrm{I} 6,5$ & 38,3 \\
\hline Krapinsko-zagorska & 7,2 & 5,5 & $\mathrm{I} 2,7$ \\
\hline Sisačko-moslavačka & 3,7 & $\mathrm{IO}, 2$ & 13,9 \\
\hline Karlovačka & 2,6 & 7,2 & 9,7 \\
\hline Varaždinska & $\mathrm{I} 2,7$ & 9,7 & 22,4 \\
\hline Koprivničko-križevačka & 9,2 & 7,0 & 16,2 \\
\hline Bjelovarsko-bilogorska & $7, \mathrm{I}$ & 5,4 & $\mathrm{I} 2,5$ \\
\hline Međimurska & 8,4 & 6,4 & $\mathrm{I} 4,8$ \\
\hline Ukupno bez Zagreba & 72,7 & 67,9 & $\mathrm{I} 40,6$ \\
\hline Grad Zagreb & III,3 & 288,3 & 399,6 \\
\hline Zagrebačka makroregija ukupno & 184,0 & 356,2 & 540,2 \\
\hline \multicolumn{4}{|l|}{ Osječka ili slavonska makroregija } \\
\hline Virovitičko-podravska & 0,6 & 8,4 & 9,0 \\
\hline Požeško-slavonska & 0,6 & 7,6 & $8, \mathrm{I}$ \\
\hline Brodsko-posavska & $\mathrm{I}, \mathrm{I}$ & 14,9 & $\mathrm{I} 6, \mathrm{O}$ \\
\hline Osječko-baranjska & 2,9 & 39,6 & 42,5 \\
\hline Vukovarsko-srijemska & $\mathrm{I}, 3$ & $\mathrm{I} 7,2$ & $\mathrm{I} 8,5$ \\
\hline Osječka makroregija ukupno & 6,4 & 87,7 & 94,I \\
\hline NUTS 2 Kontinentalna Hrvatska & 190,4 & 443,8 & 634,2 \\
\hline \multicolumn{4}{|c|}{ Riječka ili primorsko-goranska makroregija } \\
\hline Primorsko-goranska & $\mathrm{I} 7,9$ & 57,0 & 74,9 \\
\hline Ličko-senjska & $\mathrm{I}, \mathrm{O}$ & 2,9 & 3,9 \\
\hline Istarska & $\mathrm{I} 2,2$ & 38,8 & 50,9 \\
\hline Riječka makroregija ukupno & $3 \mathrm{I}, \mathrm{I}$ & 98,6 & $\mathrm{I} 29,8$ \\
\hline \multicolumn{4}{|l|}{ Splitska ili dalmatinska makroregija } \\
\hline Zadarska & $\mathrm{I} 3,7$ & 36,4 & 50,2 \\
\hline Šibensko-kninska & 8,3 & $22, \mathrm{I}$ & 30,4 \\
\hline Splitsko-dalmatinska & 35,2 & 93,4 & $\mathrm{I} 28,6$ \\
\hline Dubrovačko-neretvanska & II,9 & $3 \mathrm{I}, 5$ & 43,3 \\
\hline Splitska makroregija ukupno & 69,2 & 183,3 & 252,5 \\
\hline NUTS 2 Jadranska Hrvatska & IOO.3 & 282,0 & 382,2 \\
\hline RH ukupno & 290,7 & 725,9 & I.OI6,5 \\
\hline
\end{tabular}

†Prosječan tečaj I eura u kunama 20I2. = 7,5172.

Napomena: Za procjenu su korišteni podatci iz publikacije „Turistička aktivnost domaćeg stanovništva u 20I2. godini“, DZS i IZTZG iz travnja 20I3., na način da su „regije stalnog boravka“ koje u toj publikaciji predstavljaju statističke jedinice (Zagreb, Sjeverna Hrvatska, Slavonija, Lika, Kordun i Banija, Istra, Kvarner i Gorski kotar i Dalmacija) uz pomoć podataka o županijskim BDP-ima dezagregirane na županije i potom agregirane u makroregije. 
TABLICA A9.

Devizna bilanca turizma RH-a 2012., Procjena po NUTS 2, makroregijama i županijama u mil. eura†

\section{NUTS 2, makroregija, županija}

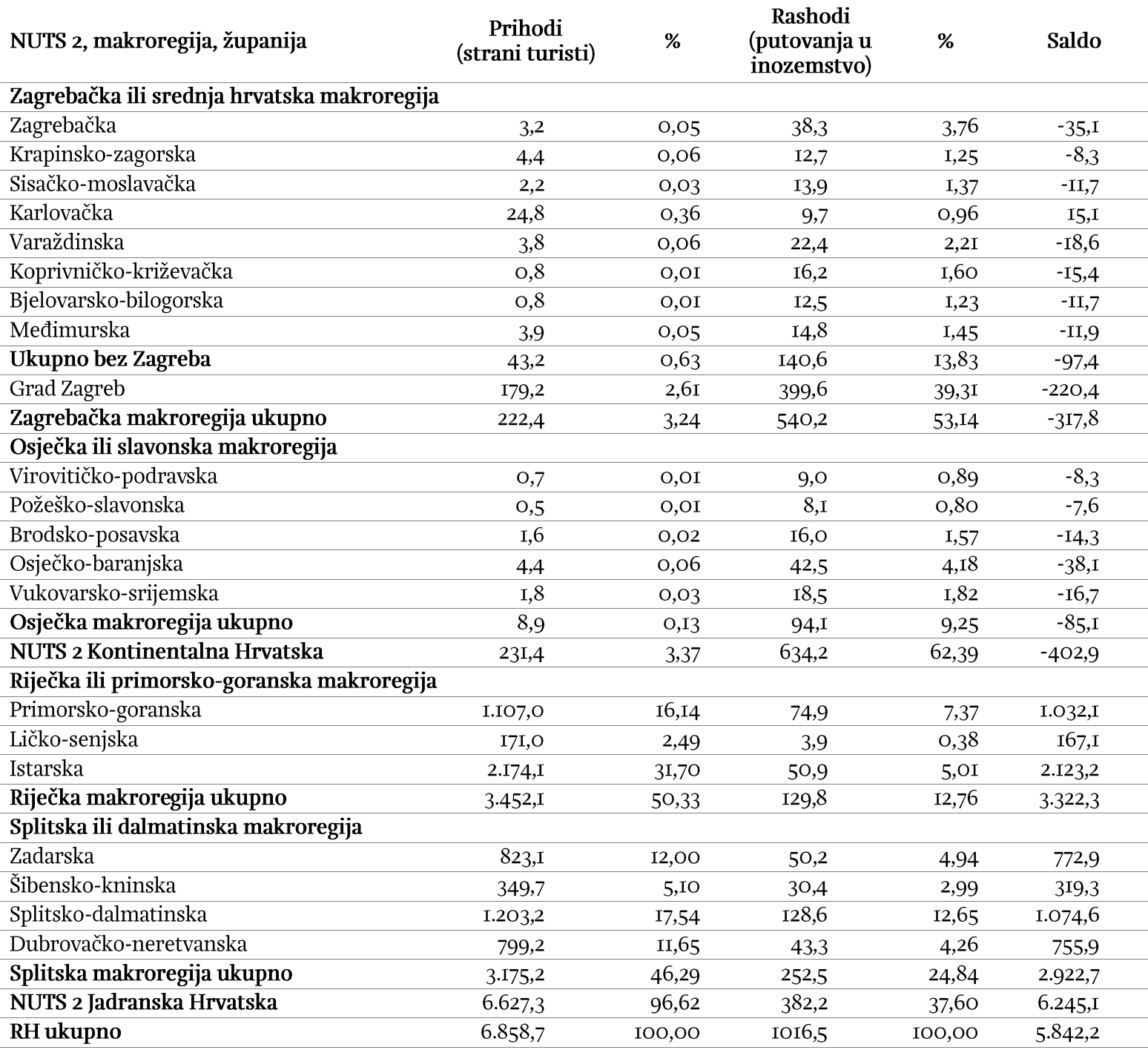

†Prosječan tečaj I eura u kunama 2012. = 7,5172.

Izvori i metodologija procjene: vidjeti tablice 6. $i$ 7. 
TABLICA Aто.

Izravna ulaganja, obveze i sredstva, po NUTS 2, makroregijama i županijama u 2012. u mil. eura†

\begin{tabular}{|c|c|c|c|c|c|}
\hline NUTS 2, makroregija, županija & Obveze & $\%$ & Sredstva & $\%$ & $\begin{array}{c}\text { Saldo } \\
\text { (obveze - } \\
\text { sredstva) }\end{array}$ \\
\hline \multicolumn{6}{|c|}{ Zagrebačka ili središnja hrvatska makroregija } \\
\hline Zagrebačka županija & $-33,4$ & $-3, \mathrm{OI}$ & $-\mathrm{I} 6 \mathrm{I}, \mathrm{O}$ & 253,39 & $\mathrm{I} 27,6$ \\
\hline Krapinsko-zagorska županija & 4,5 & 0,40 & 2,4 & $-3,79$ & $2, \mathrm{I}$ \\
\hline Sisačko-moslavačka županija & 6,8 & $0,6 \mathrm{I}$ & 0,0 & 0,00 & 6,8 \\
\hline Karlovačka županija & 2,3 & O,2I & $-0,3$ & 0,50 & 2,7 \\
\hline Varaždinska županija & $5 \mathrm{I}, 5$ & 4,64 & 7,902 & $-\mathrm{I} 2,44$ & 43,6 \\
\hline Koprivničko-križevačka županija & $-3,7$ & $-0,33$ & $-9,6$ & $\mathrm{I} 5, \mathrm{O} 4$ & 5,9 \\
\hline Bjelovarsko-bilogorska županija & 22,6 & 2,04 & $-O, I$ & $\mathrm{O}, \mathrm{I} 5$ & 22,7 \\
\hline Međimurska županija & $\mathrm{I}, 2$ & O,II & $-\mathrm{I}, \mathrm{O}$ & $\mathrm{I}, 5 \mathrm{O}$ & $2, \mathrm{I}$ \\
\hline Ukupno bez Zagreba & $5 \mathrm{I}, 7$ & 4,67 & $-I 6 I, 6$ & 254,37 & 213,4 \\
\hline Grad Zagreb & 870,6 & 78,49 & II7,3 & $-184,67$ & 753,3 \\
\hline Zagrebačka makroregija ukupno & 922,4 & $83, \mathrm{I} 5$ & $-44,3$ & 69,70 & 966,7 \\
\hline \multicolumn{6}{|l|}{ Osječka ili slavonska makroregija } \\
\hline Virovitičko-podravska županija & 0,8 & 0,07 & $\mathrm{O}, \mathrm{O}$ & 0,00 & 0,8 \\
\hline Požeško-slavonska županija & 0,8 & 0,07 & 0,0 & $\mathrm{O}, \mathrm{OO}$ & 0,8 \\
\hline Brodsko-posavska županija & 4,0 & 0,36 & 0,6 & $-0,94$ & 3,4 \\
\hline Osječko-baranjska županija & $-\mathrm{I} 7,5$ & $-\mathrm{I}, 57$ & $-\mathrm{Ig}, \mathrm{O}$ & 29,83 & $\mathrm{I}, 5$ \\
\hline Vukovarsko-srijemska županija & $-8,2$ & $-0,74$ & 0,0 & 0,00 & $-8,2$ \\
\hline Osječka makroregija ukupno & $-2 \mathrm{O}, \mathrm{I}$ & $-\mathrm{I}, 8 \mathrm{I}$ & $-18,4$ & 28,89 & $-\mathrm{I}, 7$ \\
\hline NUTS 2 Kontinentalna Hrvatska & 902,3 & $8 \mathrm{I}, 34$ & $-62,6$ & 98,59 & 964,9 \\
\hline \multicolumn{6}{|c|}{ Riječka ili primorsko-goranska makroregija } \\
\hline Primorsko-goranska županija & IOI,O & $9, \mathrm{IO}$ & $-5, \mathrm{I}$ & $8, \mathrm{I3}$ & IO6,I \\
\hline Ličko-senjska županija & 3,5 & 0,32 & 0,0 & 0,00 & 3,5 \\
\hline Istarska županija & 45,6 & $4, I I$ & $-9,6$ & $\mathrm{I} 5, \mathrm{O} 8$ & 55,2 \\
\hline Riječka makroregija ukupno & I5O,I & $\mathrm{I} 3,53$ & $-\mathrm{I} 4,7$ & 23,20 & $\mathrm{I} 64,8$ \\
\hline \multicolumn{6}{|l|}{ Splitska ili dalmatinska makroregija } \\
\hline Zadarska županija & $-22,5$ & $-2,02$ & $-34,8$ & 54,83 & $\mathrm{I} 2,4$ \\
\hline Šibensko-kninska županija & $-20,9$ & $-1,89$ & O,OI & $-0,02$ & $-2 \mathrm{I}, \mathrm{O}$ \\
\hline Splitsko-dalmatinska županija & 92,8 & 8,37 & 47,3 & $-74,39$ & 45,6 \\
\hline Dubrovačko-neretvanska županija & 7,4 & 0,67 & $\mathrm{I}, 4$ & $-2,22$ & 6,0 \\
\hline Splitska makroregija ukupno & 56,9 & 5,13 & $\mathrm{I} 3,8$ & $-2 \mathrm{I}, 8 \mathrm{O}$ & 43,0 \\
\hline NUTS 2 Jadranska Hrvatska & 207,0 & $\mathrm{I} 8,66$ & $-0,9$ & $\mathrm{I}, 4 \mathrm{O}$ & 207,8 \\
\hline RH ukupno & IIO9,2 & 100,00 & $-63,5$ & IOO,OO & $\mathrm{II} 72,8$ \\
\hline
\end{tabular}

†Prosječan tečaj г eura u kunama 20I2. = 7,5I72.

Napomena. Negativno ulaganje na Obvezama najčešće se bilježi kada: (I) poduzeće u RH djelomično ili potpuno otplati kredit koji mu je dao inozemni vjerovnik s kojim je poduzeće u RH vlasnički povezano, (2) poduzeće u RH isplati udjel u dobiti svojem inozemnom ulagaču u iznosu većem od ostvarene dobiti u istom razdoblju, $i$ (3) poduzeće u $\mathrm{RH} u$ kojem postoji registrirano inozemno ulaganje ostvari negativnu dobit u bilo kojem iznosu. Ako je situacija obrnuta (riječ je o poduzeću izvan RH koje je vlasnički povezano s ulagačem iz RH) tada se bilježi negativno ulaganje na Sredstvima.

Izvor: HNB, Sektor statistike, srpanj 2015. Metodologija za inozemna izravna ulaganja na: http://www.hnb.hr/statistika/strana-ulaganja/h-info-novametodologija.pdf. Detaljnija objašnjenja o uvođenju standarda BPM6 (Načelo imovine i obveza) umjesto BPM5 (Načelo smjera ulaganja) na: http://www.hnb.hr/statistika/esa-20Io/h-esa-prezentacija-skudar.pdf. 
TABLICA AII.

Devizni krediti kreditnih institucija nefinancijskim društvima po NUTS 2, makroregijama i županijama na kraju 20I2. u mil. eurat

\begin{tabular}{|c|c|c|c|c|c|c|}
\hline NUTS 2, makroregija, županija & $\begin{array}{c}\text { Devizni } \\
\text { krediti }\end{array}$ & $\begin{array}{l}\text { Od toga } \\
\text { kamata }\end{array}$ & $\begin{array}{c}\text { Krediti s } \\
\text { deviznom } \\
\text { klauzulom }\end{array}$ & $\begin{array}{l}\text { Od toga } \\
\text { kamata }\end{array}$ & $\begin{array}{l}\text { Devizni } \\
\text { krediti } \\
\text { ukupno }\end{array}$ & $\%$ \\
\hline \multicolumn{7}{|c|}{ Zagrebačka ili središnja hrvatska makroregija } \\
\hline Zagrebačka županija & II 4,5 & $\mathrm{I}, 2$ & 338,6 & 5,8 & $453, \mathrm{I}$ & 4,89 \\
\hline Krapinsko-zagorska županija & 14,6 & 0,3 & 82,3 & 0,9 & 96,9 & I,O5 \\
\hline Sisačko-moslavačka županija & 15,2 & $\mathrm{O}, \mathrm{I}$ & $80, \mathrm{I}$ & 0,9 & 95,2 & I,O3 \\
\hline Karlovačka županija & II, 2 & O,I & 72,5 & 0,99 & 83,7 & 0,90 \\
\hline Varaždinska županija & 65,7 & $\mathrm{I}, \mathrm{O}$ & 299,4 & 3,6 & $365, \mathrm{I}$ & 3,94 \\
\hline Koprivničko-križevačka županija & 70,8 & 0,4 & IO3,9 & I,3 & 174,7 & 1,89 \\
\hline Bjelovarsko-bilogorska županija & 8,9 & 0,2 & $\mathrm{II} 7,4$ & 2,0 & $\mathrm{I} 26,3$ & $\mathrm{I}, 36$ \\
\hline Međimurska županija & 20,5 & 0,5 & II 3,3 & $\mathrm{I}, 5$ & $\mathrm{I} 33,8$ & $\mathrm{I}, 44$ \\
\hline Ukupno bez Zagreba & $32 I, 4$ & 3,8 & $\mathrm{I} .2 \mathrm{O} 7,5$ & 16,9 & I. 528,9 & $\mathrm{I} 6,50$ \\
\hline Grad Zagreb & I.I29,8 & I5,9 & $2.527,6$ & $4 \mathrm{I}, 2$ & $3.657,4$ & 39,47 \\
\hline Zagrebačka makroregija ukupno & I.45I,I & 19,7 & $3.735, \mathrm{I}$ & $58, \mathrm{I}$ & $5.186,2$ & 55,97 \\
\hline \multicolumn{7}{|l|}{ Osječka ili slavonska makroregija } \\
\hline Virovitičko-podravska županija & 0,4 & O,OI & 74,74 & 0,7 & $75, \mathrm{I}$ & $0,8 \mathrm{I}$ \\
\hline Požeško-slavonska županija & 3,9 & 0,04 & $6 \mathrm{I}, 7$ & 0,8 & 65,6 & 0,71 \\
\hline Brodsko-posavska županija & 8,4 & $\mathrm{O}, \mathrm{I}$ & $\mathrm{I} 38,8$ & $\mathrm{I}, 9$ & $\mathrm{I} 47,2$ & $\mathrm{I}, 59$ \\
\hline Osječko-baranjska županija & 48,0 & 0,7 & 633,8 & 8,7 & $68 \mathrm{I}, 8$ & 7,36 \\
\hline Vukovarsko-srijemska županija & $8, \mathrm{I}$ & O,I & $\mathrm{I} 63,7$ & $\mathrm{I}, 5$ & $\mathrm{I} 7 \mathrm{I}, 8$ & $\mathrm{I}, 85$ \\
\hline Osječka makroregija ukupno & 68,8 & 0,9 & I.072,7 & 13,7 & I.I4I,5 & 12,32 \\
\hline NUTS 2 Kontinentalna Hrvatska & I.5I9,9 & 20,6 & $4.807,8$ & 71,9 & $6.327,7$ & 68,29 \\
\hline \multicolumn{7}{|c|}{ Riječka ili primorsko-goranska makroregija } \\
\hline Primorsko-goranska županija & III, 4 & $\mathrm{I}, 6$ & 543,8 & 8,3 & 655,2 & 7,07 \\
\hline Ličko-senjska županija & 3,6 & 0,04 & $5 \mathrm{I}, 8$ & 0,5 & 55,4 & 0,60 \\
\hline Istarska županija & II 4,9 & $\mathrm{I}, 5$ & $4 \mathrm{I} 7,9$ & 6,8 & 532,8 & 5,75 \\
\hline Riječka makroregija ukupno & 230,0 & $3, \mathrm{I}$ & I.OI3,4 & 15,6 & I.243,4 & $\mathrm{I} 3,42$ \\
\hline \multicolumn{7}{|l|}{ Splitska ili dalmatinska makroregija } \\
\hline Zadarska županija & 40,3 & 0,5 & 258,3 & 3,7 & 298,6 & 3,22 \\
\hline Splitsko-dalmatinska županija & 245,4 & 3,9 & 661,8 & IO,3 & 907,2 & 9,79 \\
\hline Šibensko-kninska županija & 2I,I & 0,3 & 199,4 & 1,9 & 220,5 & 2,38 \\
\hline Dubrovačko-neretvanska županija & 22,4 & 0,2 & 245,6 & 4,3 & 268,0 & 2,89 \\
\hline Splitska makroregija ukupno & 329,2 & 4,9 & I. 365,2 & 20,2 & I.694,4 & 18,29 \\
\hline NUTS 2 Jadranska Hrvatska & 559,2 & 8,0 & $2.378,6$ & 35,8 & $2.937,8$ & $3 \mathrm{I}, 7 \mathrm{I}$ \\
\hline RH ukupno & 2.079,I & 28,6 & $7.186,4$ & 107,7 & $9.265,5$ & IOO,OO \\
\hline
\end{tabular}

†Prosječan tečaj I eura u kunama 2012. = 7,5172.

Izvor: HNB, Sektor statistike, srpanj 2015. Metodologija prati http://www.hnb.hr/statistika/statisticki_pregled/hmetod.pdf, odnosno tablice D5 Statističkog pregleda HNB-a za institucionalne sektore. 
TABLICA AI2.

Devizni krediti kreditnih institucija kućanstvima po NUTS 2, makroregijama i županijama na kraju 20I2. u mil. eurat

\begin{tabular}{|c|c|c|c|c|c|c|}
\hline NUTS 2, makroregija, županija & $\begin{array}{l}\text { Devizni } \\
\text { krediti }\end{array}$ & $\begin{array}{l}\text { Od toga } \\
\text { kamata }\end{array}$ & $\begin{array}{c}\text { Krediti s } \\
\text { deviznom } \\
\text { klauzulom }\end{array}$ & $\begin{array}{l}\text { Od toga } \\
\text { kamata }\end{array}$ & $\begin{array}{c}\text { Devizni } \\
\text { krediti } \\
\text { ukupno }\end{array}$ & $\%$ \\
\hline \multicolumn{7}{|c|}{ Zagrebačka ili središnja hrvatska makroregija } \\
\hline Zagrebačka & $\mathrm{I}, 8$ & 0,069 & I.243,9 & 7,7 & $\mathrm{I} .245,7$ & 9,40 \\
\hline Krapinsko-zagorska & 0,3 & 0,005 & 3OI,O & $2, \mathrm{I}$ & 301,2 & 2,27 \\
\hline Sisačko-moslavačka & 0,4 & O,OI9 & 402,6 & 2,2 & 4O3,I & 3,04 \\
\hline Karlovačka & 0,4 & 0,004 & 260,5 & $\mathrm{I}, 5$ & 260,9 & 1,97 \\
\hline Varaždinska & 0,6 & 0,009 & 423,9 & 2,5 & 424,5 & 3,20 \\
\hline Koprivničko-križevačka & 0,4 & 0,003 & 266,5 & $\mathrm{I}, 7$ & 266,9 & $2, \mathrm{OI}$ \\
\hline Bjelovarsko-bilogorska & 0,04 & O,OOI & 254,4 & $\mathrm{I}, 5$ & 254,5 & 1,92 \\
\hline Međimurska & $\mathrm{I}, 8$ & 0,009 & 245,5 & $\mathrm{I}, 3$ & 247,2 & $\mathrm{I}, 87$ \\
\hline Ukupno bez Zagreba & 5,7 & 0,120 & $3 \cdot 398,2$ & 20,4 & $3.403,9$ & 25,68 \\
\hline Grad Zagreb & $\mathrm{I} 2,2$ & 0,137 & 3.63I,I & $2 \mathrm{I}, 8$ & $3.643,3$ & 27,49 \\
\hline Zagrebačka makroregija ukupno & 17,9 & 0,257 & $7.029,3$ & 42,2 & $7.047,2$ & 53,17 \\
\hline \multicolumn{7}{|l|}{ Osječka ili slavonska makroregija } \\
\hline Virovitičko-podravska & 0,07 & O,OOI & 159,2 & $\mathrm{I}, \mathrm{O}$ & 159,3 & 1,20 \\
\hline Požeško-slavonska & O,OI & 0,000 & $\mathrm{I} 62,4$ & $\mathrm{I}, \mathrm{O}$ & $\mathrm{I} 62,4$ & $\mathrm{I}, 23$ \\
\hline Brodsko-posavska & 0,3 & O,OII & 339,8 & $2, \mathrm{I}$ & $340, I$ & 2,57 \\
\hline Osječko-baranjska & 0,2 & o,006 & $824, \mathrm{I}$ & 4,9 & 824,2 & 6,22 \\
\hline Vukovarsko-srijemska & 0,04 & O,OOI & 331,2 & 2,0 & $33 \mathrm{I}, 2$ & 2,50 \\
\hline Osječka makroregija ukupno & 0,6 & O,OI9 & I.8I6,6 & IO, 8 & I.8I7,2 & $\mathrm{I} 3,7 \mathrm{I}$ \\
\hline NUTS 2 Kontinentalna Hrvatska & $\mathrm{I} 8,5$ & 0,276 & $8.845,9$ & $53, \mathrm{I}$ & $8.864,4$ & 66,88 \\
\hline \multicolumn{7}{|c|}{ Riječka ili primorsko-goranska makroregija } \\
\hline Primorsko-goranska & 0,3 & 0,004 & I.067,5 & 5,4 & I.067,8 & 8,06 \\
\hline Ličko-senjska & 0,4 & 0,008 & II 7,5 & 0,7 & II 7,9 & 0,89 \\
\hline Istarska & 0,7 & O,OI5 & $8 \mathrm{I} 2,5$ & 4,5 & $8 \mathrm{I} 3,2$ & $6, \mathrm{I} 4$ \\
\hline Riječka makroregija ukupno & $\mathrm{I}, 4$ & 0,027 & I.997,5 & IO,6 & I.998,9 & $\mathrm{I} 5,08$ \\
\hline \multicolumn{7}{|l|}{ Splitska ili dalmatinska makroregija } \\
\hline Zadarska & 3,0 & O,O7I & $483, I$ & 2,9 & $486, I$ & 3,67 \\
\hline Šibensko-kninska & 0,04 & 0,002 & $224, \mathrm{I}$ & $\mathrm{I}, 8$ & $224, I$ & 1,69 \\
\hline Splitsko-dalmatinska & 4,8 & 0,074 & I.199,3 & $7, \mathrm{I}$ & $\mathrm{I} .2 \mathrm{O} 4, \mathrm{I}$ & 9,09 \\
\hline Dubrovačko-neretvanska & 6,4 & 0,078 & 469,3 & 2,2 & 475,7 & 3,59 \\
\hline Splitska makroregija ukupno & $\mathrm{I} 4,2$ & 0,225 & $2.375,9$ & $14, \mathrm{O}$ & $2.390, \mathrm{I}$ & 18,03 \\
\hline NUTS 2 Jadranska Hrvatska & 15,6 & 0,252 & $4,373,3$ & 24,6 & $4.389,0$ & $33, \mathrm{I} 2$ \\
\hline RH ukupno & $34, \mathrm{I}$ & 0,527 & I3.219,3 & 77,6 & I3.253,4 & IOO,OO \\
\hline
\end{tabular}

†Prosječan tečaj I eura u kunama 2012. = 7,5172.

Izvor: HNB, Sektor statistike, srpanj 2015. Metodologija prati: http://www.hnb.hr/statistika/statisticki_pregled/hmetod.pdf, odnosno tablice D5 Statističkog pregleda HNB-a za institucionalne sektore. 
TABLICA AI3.

Devizni depoziti nefinancijskih društava po NUTS 2, makroregijama i županijama na kraju 20I2. u mil. eurat

\begin{tabular}{|c|c|c|c|}
\hline NUTS 2, makroregija, županija & Devizni depoziti & Od toga kamata & Depoziti \% \\
\hline \multicolumn{4}{|c|}{ Zagrebačka ili središnja hrvatska makroregija } \\
\hline Zagrebačka & 65,5 & 0,4 & 2,86 \\
\hline Krapinsko-zagorska & 48,4 & $\mathrm{O}, \mathrm{I}$ & $2, \mathrm{II}$ \\
\hline Sisačko-moslavačka & 27,4 & O,I & $\mathrm{I}, 2 \mathrm{O}$ \\
\hline Karlovačka & $\mathrm{I} 8, \mathrm{O}$ & $\mathrm{O}, \mathrm{I}$ & 0,79 \\
\hline Varaždinska & 45,9 & 0,4 & 2,00 \\
\hline Koprivničko-križevačka & $\mathrm{I} 5,4$ & $\mathrm{O}, \mathrm{I}$ & 0,67 \\
\hline Bjelovarsko-bilogorska & 6,3 & O,I & 0,27 \\
\hline Međimurska & 45,7 & 0,2 & 2,00 \\
\hline Ukupno bez Zagreba & 272,6 & $\mathrm{I}, 6$ & II,9O \\
\hline Grad Zagreb & I.O93,8 & 7,3 & 47,74 \\
\hline Zagrebačka makroregija ukupno & I. 366,4 & 8,9 & 59,64 \\
\hline \multicolumn{4}{|l|}{ Osječka ili slavonska makroregija } \\
\hline Virovitičko-podravska & $2 \mathrm{I}, 5$ & 0,7 & 0,94 \\
\hline Požeško-slavonska & 6,4 & $\mathrm{O}, \mathrm{O} 2$ & 0,28 \\
\hline Brodsko-posavska & 15,7 & 0,2 & 0,69 \\
\hline Osječko-baranjska & $28, \mathrm{I}$ & $\mathrm{O}, \mathrm{O} 4$ & I,23 \\
\hline Vukovarsko-srijemska & $\mathrm{I} 2,9$ & $\mathrm{O}, \mathrm{O} 4$ & 0,56 \\
\hline Osječka makroregija ukupno & 84,6 & 0,9 & 3,69 \\
\hline NUTS 2 Kontinentalna Hrvatska & $\mathrm{I} .45 \mathrm{I}, \mathrm{O}$ & 9,8 & 63,33 \\
\hline \multicolumn{4}{|c|}{ Riječka ili primorsko-goranska makroregija } \\
\hline Primorsko-goranska & $\mathrm{I} 27,8$ & 0,7 & 5,58 \\
\hline Ličko-senjska & $2, \mathrm{I}$ & $\mathrm{O}, \mathrm{O} 2$ & O,o9 \\
\hline Istarska & 381,8 & 3,2 & 16,67 \\
\hline Riječka makroregija ukupno & $5 \mathrm{II}, 7$ & 3,9 & 22,34 \\
\hline \multicolumn{4}{|l|}{ Splitska ili dalmatinska makroregija } \\
\hline Zadarska & $6 \mathrm{I}, 2$ & $\mathrm{I}, \mathrm{O}$ & 2,67 \\
\hline Šibensko-kninska & II,4 & O,I & 0,50 \\
\hline Splitsko-dalmatinska & I3O,I & O,I & 5,68 \\
\hline Dubrovačko-neretvanska & I25,6 & 0,9 & 5,48 \\
\hline Splitska makroregija ukupno & 328,3 & 2,9 & 14,33 \\
\hline NUTS 2 Jadranska Hrvatska & 840,0 & 6,7 & 36,67 \\
\hline RH ukupno & $2.291,0$ & 16,5 & IOO,OO \\
\hline
\end{tabular}

†Prosječan tečaj I eura u kunama 2012. = 7,5172.

Izvor: HNB, Sektor statistike, srpanj 2015. Napomena: Devizni depoziti uključuju devizne depozite i kunske depozite uz valutnu klauzulu. Metodologija prati: http://www.hnb.hr/statistika/statisticki_pregled/hmetod.pdf, odnosno tablice D5 Statističkog pregleda HNB-a za institucionalne sektore. 


\section{TABLICA AI4.}

Devizni depoziti kućanstava po NUTS 2, makroregijama i županijama na kraju 20I2. u mil. eura ${ }^{\dagger}$

\begin{tabular}{|c|c|c|c|}
\hline NUTS 2, makroregija, županija & Devizni depoziti & Od toga kamata & Depoziti \% \\
\hline \multicolumn{4}{|c|}{ Zagrebačka ili središnja hrvatska makroregija } \\
\hline Zagrebačka & $\mathrm{I} .229,6$ & 19,2 & $6,6 \mathrm{I}$ \\
\hline Krapinsko-zagorska & 263,9 & 4,7 & $\mathrm{I}, 42$ \\
\hline Sisačko-moslavačka & 292,0 & 3,6 & $\mathrm{I}, 57$ \\
\hline Karlovačka & $363, I$ & $5, \mathrm{I}$ & I,95 \\
\hline Varaždinska & 440,2 & 7,I & 2,37 \\
\hline Koprivničko-križevačka & 237,8 & 3,5 & $\mathrm{I}, 28$ \\
\hline Bjelovarsko-bilogorska & 295,0 & 4,4 & 1,59 \\
\hline Međimurska & 399,2 & 4,2 & $2, \mathrm{I} 5$ \\
\hline Ukupno bez Zagreba & $3.520,7$ & $5 \mathrm{I}, 8$ & I8,94 \\
\hline Grad Zagreb & $5 \cdot 383,3$ & 77,6 & 28,95 \\
\hline Zagrebačka makroregija ukupno & $8.904,0$ & $\mathrm{I} 29,3$ & 47,89 \\
\hline \multicolumn{4}{|l|}{ Osječka ili slavonska makroregija } \\
\hline Virovitičko-podravska & $\mathrm{I} 32,8$ & 2,0 & $\mathrm{O}, 7 \mathrm{I}$ \\
\hline Požeško-slavonska & $\mathrm{I} 83,2$ & 3,3 & 0,99 \\
\hline Brodsko-posavska & 358,3 & $5, \mathrm{I}$ & $\mathrm{I}, 93$ \\
\hline Osječko-baranjska & 727,3 & II,5 & 3,91 \\
\hline Vukovarsko-srijemska & 273,0 & 3,8 & $\mathrm{I}, 47$ \\
\hline Osječka makroregija ukupno & I.674,6 & 25,7 & 9,OI \\
\hline NUTS 2 Kontinentalna Hrvatska & I0.578,6 & $\mathrm{I} 55, \mathrm{I}$ & 56,90 \\
\hline \multicolumn{4}{|c|}{ Riječka ili primorsko-goranska makroregija } \\
\hline Primorsko-goranska & I.769,3 & 22,0 & 9,52 \\
\hline Ličko-senjska & 172,9 & 2,8 & 0,93 \\
\hline Istarska & I.3I3,5 & $\mathrm{I} 7,8$ & 7,06 \\
\hline Riječka makroregija ukupno & $3.255,7$ & $4 \mathrm{I}, 8$ & $\mathrm{I} 7,5 \mathrm{I}$ \\
\hline \multicolumn{4}{|l|}{ Splitska ili dalmatinska makroregija } \\
\hline Zadarska & 849 & 9,9 & 4,57 \\
\hline Šibensko-kninska & 519,6 & 4,2 & 2,79 \\
\hline Splitsko-dalmatinska & $2.623, \mathrm{I}$ & 38,5 & I4,II \\
\hline Dubrovačko-neretvanska & 765,7 & 9,4 & $4, \mathrm{I} 2$ \\
\hline Splitska makroregija ukupno & $4.757,8$ & 61,9 & 25,59 \\
\hline NUTS 2 Jadranska Hrvatska & $8.013,6$ & IO3,7 & $43, \mathrm{IO}$ \\
\hline RH ukupno & I8.592,2 & 258,8 & IOO,OO \\
\hline
\end{tabular}

†Prosječan tečaj I eura u kunama 2012. = 7,5172.

Izvor: HNB, Sektor statistike, srpanj 2015. Napomena: Devizni depoziti uključuju devizne depozite i kunske depozite uz valutnu klauzulu. Metodologija prati: http://www.hnb.hr/statistika/statisticki_pregled/hmetod.pdf, odnosno tablice D5 Statističkog pregleda HNB-a za institucionalne sektore. 


\section{REFERENCE}

I. Abreu, M. [et al.], 2008. Absorptive Capacity and Regional Patterns of Innovation Centre for Business Research (CBR). University of Cambridge DIUS Research Report, No. o8 II. Dostupno na: 〈http://dera.ioe.ac.uk/8752/I/DIUS-RR-o8-II.pdf〉.

2. Alderman, N. i Davies, S., 1990. Modelling regional patterns of innovation diffusion in the UK metalworking industries. Regional Studies, 24, str. 513-528. doi: 10.1080/00343409012331346184

3. Babić, A. i Babić, M., 2008. Međunarodna ekonomija. Zagreb: Sigma savjetovanje.

4. Babić, A., 20oo. Komentar o devalvaciji. Ekonomija moderna, I-3.

5. Bajo, A. [et al.], 20I4. Učinci decentralizacije u Republici Hrvatskoj na ekonomski i fiskalni položaj Istarske županije. Zagreb: Institut za javne financije.

6. Barca, F., McCann, P. i Rodriguez-Pose, A., 2012. The case for regional development intervention: place-based versus place-neutral approaches. Journal of Regional Science, 52(I), str. 134-152. doi: IO.IIII/j.I467-9787.20II.00756.X

7. Brnić, M., 2015. Izvoznici traže prilagodbu tečaja u razmjeru od 2 posto godišnje, izvješće s Desete konvencije hrvatskih izvoznika. Poslovni dnevnik, June I, 2015.

8. Camagni, R., 2015. Macroeconomic constraints and spatial strategies in renewed cohesion policies. RSA Winter Conference Great Transformation: Recasting Regional Policy, Igth - 2oth November.

9. Capello, R. i Nijkamp, P., eds., 2009. Regional growth and development theories in the XXI Century. Cheltenham: Edwar Elgar. doi: 10.4337/9781848445987

Io. CBS i IZTZG, 2013. Turistička aktivnost domaćeg stanovništva u 20I2. godini. Zagreb: Croatian Bureau of Statistics and Institute of Tourism.

II. CBS, 1994. Statistički ljetopis hrvatskih županija, Godina I- 1993. Zagreb: Croatian Bureau of Statistics.

12. CBS, 2012. Popis stanovništva, kućanstava i stanova 20II. godine. Zagreb: Croatian Bureau of Statistics.

13. CBS, 2013a. Priopćenje broj 4.2.4. Robna razmjena Republike Hrvatske s inozemstvom po županijama, gradovima i općinama u 20I2. - konačni podatci. Zagreb: Croatian Bureau of Statistics.

I4. CBS, 20I3b. Statistička izvješća I49I. Zagreb: Croatian Bureau of Statistics.

15. CBS, 20I5a. Priopćenje, I2.I.6. Bruto domaći proizvod za Republiku Hrvatsku, NKPJS - 2. razina i županije za razdoblje 2000.-2012. (ESA 2010). Zagreb: Croatian Bureau of Statistics.

16. CBS, 2OI5b. Statistički ljetopis 20I4. Zagreb: Croatian Bureau of Statistics.

17. Cesarano, F., 2006. Optimum currency areas: a policy view. BNL Quarterly Review, 40(239), str. 317332.

18. CNB, 20I5a. Klasifikacija i iskazivanje podataka o potraživanjima i obvezama. Zagreb: Croatian national bank. Dostupno na: 〈http://www.hnb.hr/statistika/statisticki_pregled/hmetod.pdf〉.

19. CNB, 20I5b. Informacija o novoj metodologiji kompilacije pozicije Izravna ulaganja u sklopu platne bilance. Zagreb: Croatian national bank. Dostupno na: <http://www.hnb.hr/statistika/stranaulaganja/h-info-nova-metodologija.pdf $>$.

20.Dellas, H. i Tavlas, G. S., 2009. An optimum-currency-area odyssey. Bank of Greece Working paper, No. 02 .

21. European Commission, 2013. European System of Accounts - ESA 2010. Dostupno na: <http://ec.europa.eu/eurostat/documents/3859598/5925693/KS-O2-I3-269-EN.PDF/44cd9doi-bc64-40e5-bd4o-di7dfoc69334>.

22. Filipić, P. i Grčić, B., 20O2. Evaluation of regional development and (im)balances: the Croatian case. The Journal of Management Science \& Regional Development (MSRD), (4), str. 2I-36.

23. Filipić, P., 2000. The Regional Impact of macroeconomic Policy: the Case of Countries in Transition, Local Development in Central and Eastern Europa, Universita degli studi di Ancona, str. 3I-35.

24. Filipić, P., 200I. The regional impact of monetary policy: The Island case. The First Encounter of Mediterranean Economists. CD ROM full paper. Split: Faculty of Economics.

25. Filipić, P., 2006. Makroekonomija za svakoga. Split: Slobodna Dalmacija : Faculty of Economics.

26.Galinec, D., 200o. Statističko evidentiranje pozicije putovanja - Turizam u platnoj bilanci Republike Hrvatske. HNB, Istraživanja, I-3. Zagreb: Croatian national bank.

27. Gatarić, LJ., 2015. Dužnici čekaju ponudu banaka ili će na sud. Večernji list, May 15, 2015.

28.IMF, 2009. Balance of payments and international investment position manual. Washington: IMF.

29. IZTZG, 2013. Stavovi i potrošnja turista u Hrvatskoj. Zagreb: IZTZG.

30.IZTZG, 20I4. Stavovi i potrošnja turista i posjetitelja Zagreba. Zagreb: IZTZG.

31. Leksikografski zavod Miroslav Krleža, 2013-2OI5. Hrvatska enciklopedija. 
32. Mundell, R. A., 1963. A Theory of Optimum Currency Area. American Economic Review, 5I, str. 65765.

33. Ramos, N. P., 2006. Does the balance-of-payments matter at the regional level?. 46th Congress of the European Regional Science Association, Volos, Greece August 3oth - September 3rd.

34. Ramos, N. P., 2007. Does the trade balance really matter for regions? The Annals of Regional Science, 4I(I), str. 229-243. doi: 10.1007/sool68-006-009I-5

35. Škudar, A., 2OI4. Uvođenje standarda BPM6 u statistike odnosa s inizemstvom - PPT presentation. Dostupno na: <http://www.hnb.hr/statistika/esa-201o/h-esa-prezentacija-skudar.pdf >.

36.UK

Trend

info,

2015.

Dostupno

na:

〈https://www.uktradeinfo.com/Statistics/RTS/Pages/default.aspx>.

37. World Bank, 2015. Personal remittances, received (current US\$). Dostupno na: $\langle$ http://data.worldbank.org/indicator/BX.TRF.PWKR.CD.DT〉

38.Zakon o regionalnom razvoju Republike Hrvatske, NN 147/14.

39.Zakon o službenoj statistici, NN 103/O3, 75/O9, 52/12.

40. 